\title{
ABSTRAK \\ STUDI KASUS KEBIDANAN PADA IBU HAMIL DENGAN NYERI PUNGGUNG DI WILAYAH PUSKESMAS WONOMULYO KABUPATEN POLEWALI MANDAR
}

\author{
Lina Fitriani ${ }^{1}$, Fransiska firna $^{2}$, Rezky Awalya ${ }^{3}$, Riska Renita $^{4}$
}

Latar Belakang : Masa kehamilan di mulai dari kontrasepsi sampai lahirnya janin lamanya hamil normal adalah 280 hari (40 minggu atau 9 bulan 7 hari) di hitung dari hari pertama haid terakhir.

Tujuan : Mampu melaksanakan Asuhan Kebidanan pada ibu hamil dengan nyeri punggung di wilayah Puskesmas Wonomulyo.

Metode Penelitian : Pendekatan yang di gunakan adalah studi kasus, subjek penelitian yaitu 2 ibu hamil di Puskesmas Wonomulyo. Objek penelitian adalah Studi Kasus Kebidanan Pada Ibu Hamil Dengan Nyeri Punggung. Teknik pengambilan data menggunakan 7 langkah varney, di dokumentasikan dalam bentuk SOAP.

Hasil Penelitian: Didapatkan ibu mengalami nyeri punggung dan saring kencing, pada kasus Ny"H" dan Ny"H" nyeri punggung dan sering kencing di atasi dengan senam hamil dan senam yoga nyesi punggung dan sering kecing dapat di atasi jika asuhan yang diberikan di lakasanakan dengan maksimal.

Kesimpulan: Setelah penkajian, interpertasi data , diagnosa potensial, tindakan segera, perencenaan,pelaksanaan dan evaluasi pada ibu hamil dengan nyeri punggung tidak ada kesenjagan antara teori pelaksanaan studi kasus selama 5 hari pasien sudah dalam keadaan baik.

Kata kunci :Asuhan kebidanan, ibu hamil, nyeri punggung

Kepustakaan : 15 buku +11 jurnal

\begin{abstract}
MIDWIFERY CASE STUDIES IN PREGNANT WOMEN WITH BACK PAIN IN THE

WONOMULYO HEALTH CENTER AREA OF POLEWALI MANDAR DISTRICT
\end{abstract}

Lina Fitriani ${ }^{1}$, Fransiska firna ${ }^{2}$, Rezky Awalya ${ }^{3}$, Riska Renita ${ }^{4}$

Background : The period of pregnancy starst from conception until the birth of the fetus. The duration of normal pregnancy is 280 days (40 weeks or 9 month 7 days) calculated from the first day of the last period. 
Aim : Able to carry out midwifery care for pregnant women with back pain in the wonomulyo health center.

Research methods : The approach used is a case study, the research subject is 2 pregnant women at the Wonomulyo health center. The object of the study was a midwifery case study in pregnant women with back pain. Data collection techniques use 7 varney steps, dokumented in the form of SOAP.

Research result : Found the mother to experience back pain and frequent urination, in the case of Mrs. " $H$ " dan Mrs. " $H$ " back pain and frequent urination overcome with pregnancy exercise and yoga exercises. Back pain and frequent urination can be overcome if the care provided is carried out optimally.

Conclusion : After the study, data interpretation, diagnosis potential, immediate action, planning, implementation and evalution there are pregnant woment with back pain who have no gap between the theory of case study implementation for 5 days the patient is in good condition.

Keywords : Midwifery care, pregnant mother, back pain.

Literature : 15 books + 11 journals.

\section{PENDAHULUAN}

\section{Latar belakang}

Masa kehamilan dimulai dari konsepsi sampai lahirnya janin. Lamanya hamil normal adalah 280 hari (40 minggu atau 9 bulan 7 hari) dihitung dari hari pertama haid terakhir. Kehamilan dibagi dalam 3 triwulan yaitu triwulan pertama dimulai dari kontrasepsi sampai 3 bulan, triwulan kedua dari bulan keempat sampai 6 bulan, triwulan ketiga dari bulan ketujuh sampai sembilan bulan (Sarwojo prawiroharjo, 2009)

Kehamilan melibatkan perubahan fisik maupun emosional dari ibu serta perubahan sosial di dalam keluarga. Jarang seorang ahli medik terlatih yang begitu terlibat dalam kondisi yang biasanya sehat dan normal. Mereka menghadapi suatu tugas yang tidak biasa dalam memberikan dukungan pada ibu dan keluarga dalam rencana menyambut anggota keluarga baru, memantau perubahan-perubahan fisik yang normal yang dialami ibu serta tumbuh kembang janin, juga mendeteksi serta menatalaksanakan setiap kondisi yang tidak normal. Pada umumnya kehamilan berkembang dengan normal dan menghasilkan kelahiran bayi sehat cukup bulan melalui jalan lahir namun kadangkadang tidak sesuai dengan yang diharapkan. Sulit untuk diketahui sebelumnya bahwa kehamilan akan menjadi masalah. Sistem penilaian resiko tidak dapat memprediksi apakah ibu hamil akan bermasalah selama kehamilannya. 
Oleh karena itu pelayanan/asuhan antenatal merupakan cara penting untuk memonitori dan mendukung kesehatan ibu hamil normal dan medeteksi ibu hamil dengan kehamilan normal (Sarwono Prawiroharjo,2009)

Nyeri punggung bawah adalah suatu sindroma klinik yang ditandai dengan gejala utama adanya rasa nyeri atau perasaan tidak enak di daerah tulang punggung bawah. Nyeri punggung bawah sering menjadi kronis, menetap atau kadang berulang kali dengan memerlukan biaya tinggi dalam penanganannya sehingga tidak boleh dipandang sebelah mata. Karena kebanyakan kasus nyeri punggung bukan disebabkan oleh kelainan organik, melainkan oleh kesalahan posisi tubuh dalam bekerja.(Muheri,2010)

Kehamilan dibagi menjadi tiga trimester, selama kehamilan ibu hamil dianjurkan melakukan antenatal minimal 4 kali untuk mengetahui masalah kesehatan selama kehamilan, apakah masalah tersebut bersifat fisiologi atau masalah tersebut bersifat patologis yang dapat mengancam kehamilan. Komplikasi yang mungkin terjadi selama kehamilan antara lain hipermesis gravidarum, perdarahan, anemia, eklamsia, nyeri perut hebat (Prawiroharjo, 2010).

Ketidaknyamanan kehamilan trimester III meliputi: peningkatan frekuensi berkemih/nokturia, konstipasi/sembelit,odema, insomnia, nyeri punggung, keringat berlebihan dan sebagiannya. Tidak semua wanita mengalami ketidaknyamanan yang umumnya muncul selama kehamilan, tetapi banyak wanita mengalaminya dalam tingkat ringan hingga berat (Rukiyah dkk,2009)

Pelayanan kesehatan ibu hamil di berikan pada ibu hamil yang dilakukan oleh tenaga kesehatan di fasilitasi pelayanan kesehatan. Proses ini di lakukan selama rentang usia kehamilan ibu yang di kelompokkan sesuai usia kehamilan menjadi trimester pertama, trimester kedua, dan trimester ke tiga. Selain elemen tindakan yang harus di penuhi, pelayanan kesehatan ibu hamil juga harus memenuhi frekuensi di tiap trimester, yaitu satu kali pada trimester pertama (usia kehamilan 0-12 minggu), satu kali trimester kedua (usia kehamilan 12-24 minggu), dan dua kali pada trimester ketiga (usia kehamilan 24 minggu sampai persalinan).

Standar waktu pelayanan tersebut dianjurkan untuk menjamin perlindungan terhadap ibu hamil dan janin berupa deteksi dini faktor resiko, pencengahan dan penanganan dini komplikasi kehamilan (Kementrian RI, 2015).

Menurut World Health Organitation (WHO) tahun 2012, sebanyak 585.000 kematian ibu saat hamil dan persalinan. Sebanyak $99 \%$ diakibatkan oleh persalinan terjadi di negara-negara berkembang. Rasio angka kematian ibu (AKI) dinegara-negara berkembang merupakan yang tertinggi dengan 450 kematian ibu per 100.000 kelahiran hidup. 
Berdasarkan Survei Demografi Kesehatan Indonesia (SDKI) Tahun 2012 angka kematian ibu (AKI) di indonesia mencapai 359 kematian per 100.000 kelahiran hidup. Angka tersebut masih jauh Millenium Developmant Goals (MDGs) yang sudah harus tercapai adalah pada tahun 2015 yaitu 102 kematian per 100.000 kelahiran hidup (Susanto, C E, 2011)

Bersadarkan Kemetrian Kesehatan Indonesia (Kemenkes RI) tahun 2016, jumlah ibu hamil indonesia mencapai 5.354.549 orang. Sedangkan jumlah ibu hamil di Provensi Sulawesi Barat tahun 2016 sebesar 35.437 orang (Kemenkes RI. 2016)

Menurut data ibu hamil Dines Kesehatan Polewali Mandar pada tahun 2017 sebanyak 10233 orang, jumlah ibu hamil di puskesmas wonomulyo Kabupaten Polewali Mandar pada tahun 2017 sebanyak 884 orang (Dinkes Polewali Mandar, 2017).

\section{METODE PENELITIAN}

\section{Pendekatan}

Pendekatan yang digunakan adalah studi kasus. Penelitian studi kasus adalah studi yang mengeksplorasi satu masalah kebidanan batasan terperinci, memiliki pengambilan data yang mendalam menyertakan berbagai sumber informasi. Penelitian studi kasus dibatasi oleh waktu dan tempat, serta kasus yang dipelajari berupa peristiwa, aktivitas atau individu (Nototmodjo, 2012).

Dalam hal inipeneliti ingin menggambarkan studi kasus asuhan kebidanan pada ibu hamil dengan nyeri punggung. Pendekatan yang digunakan pada studi kasus dalam penelitian ini adalah "Studi kasus asuhan kebidanan pada ibu hamil trimester III dengan nyeri punggung di Puskesmas Wonomulyo".

\section{Lokasi dan Waktu Penelitian}

Lokasi merupakan tempat pengambilan kasus dilaksanakan (Notoatmodjo, 2010). Studi kasus dilaksanakan di Puskesmas Wonomulyo. Waktu studi kasus adalah rentang waktu yang digunakan penulis untuk mencari kasus (Notoatmodjo, 2010). Studi kasus ini dilaksanakan pada bulanapril-juni 2018.

\section{Subyek Penelitian}

Pada sub bab ini di deskripsikan tentang karakteristik subyek penelitian/kasus yang akan diteliti tentang asuhan ibu hamil trimester III. Subyek penelitian yang akan digunakan adalah 2 pasien ibu hamil dengan nyeri punggung yang dilaksanakan selama \pm 5 hari. 


\section{HASIL PENELITIAN DAN PEMBAHASAN}

\section{A. Pengkajian}

\section{1) Identitas pasien dan hasil anamnesis}

\begin{tabular}{|l|l|l|}
\hline \multicolumn{1}{|c|}{$\begin{array}{c}\text { IDENTITAS } \\
\text { PASIEN }\end{array}$} & \multicolumn{1}{|c|}{ Kasus 1 } & \multicolumn{1}{c|}{ Kasus 2 } \\
\hline Nama & Ny"H"/Tn"A" & Ny"H"/Tn"A" \\
Umur & 35 thn/36 thn & 28 thn/ 28 thn \\
Agama & islam/islam & Islam/islam \\
Pendidikan & SMP/SD & SMP/SMP \\
Pekerjaan & IRT/Wiraswasta & IRT/Wiraswasta \\
Suku/Bangsa & Mandar/Indonesia & Jawa/Indonesia \\
Alamat & Sidodadi & Sumberjo \\
Hari pertama haid & 20-09-2017 & 01-10-2017 \\
terakhir (HPHT) & & \\
GPA & & \\
Keluhan Utama & GIIIPIIA0 & GIP0A0 \\
& Sering buang air kecil dan & Sering merasakan sakit \\
& nyeri bagian punggung & pada bagian punggung
\end{tabular}

\begin{tabular}{|c|c|c|}
\hline Pola Eliminasi & $\begin{array}{l}\text { Sebelum Hamil : Makan 3x/ } \\
\text { hari, sayur, lauk dan nasi. } \\
\text { Minum 6-7x/hari gelas } \\
\text { sehari (air putih). } \\
\text { Selama Hamil : Makan 3- } \\
\text { 4x/hari, dengan lauk yang } \\
\text { sama. Minum 9-10x/ hari } \\
\text { (air putih dan susu). } \\
\text { Sebelum Hamil : BAB } \\
\text { 1x/hari, warna: kuning, } \\
\text { konsistensi :lunak, bau:khas. } \\
\text { BAK 5x/hari, warna: kuning } \\
\text { jernih, bau:khas. } \\
\text { Selama hamil : BAB 1x } \\
\text { /hari, warna:kuning, } \\
\text { bau:khas, konsistensi: lunak. } \\
\text { BAK 8-10x/hari warna: } \\
\text { kuning jernih, bau:khas. }\end{array}$ & $\begin{array}{l}\text { Sebelum Hamil : Makan } \\
\text { 2x/ hari, sayur , lauk dan } \\
\text { nasi. Minum 5-6x/ hari } \\
\text { gelas sehari (air putih). } \\
\text { Selama Hamil : Makan 3- } \\
\text { 4x/hari, dengan lauk yang } \\
\text { sama. Minum 8-9x/ hari } \\
\text { (air putih dan susu). } \\
\text { Sebelum Hamil : BAB } \\
\text { 1x/hari, warna: kuning, } \\
\text { konsistensi :lunak, } \\
\text { bau:khas. BAK 6x/hari, } \\
\text { warna: kuning jernih, } \\
\text { bau:khas. } \\
\text { Selama hamil : BAB 1x } \\
\text { /hari, warna:kuning, } \\
\text { bau:khas, konsistensi: } \\
\text { lunak. BAK 8-9x/hari } \\
\text { warna: kuning jernih, } \\
\text { bau:khas }\end{array}$ \\
\hline
\end{tabular}




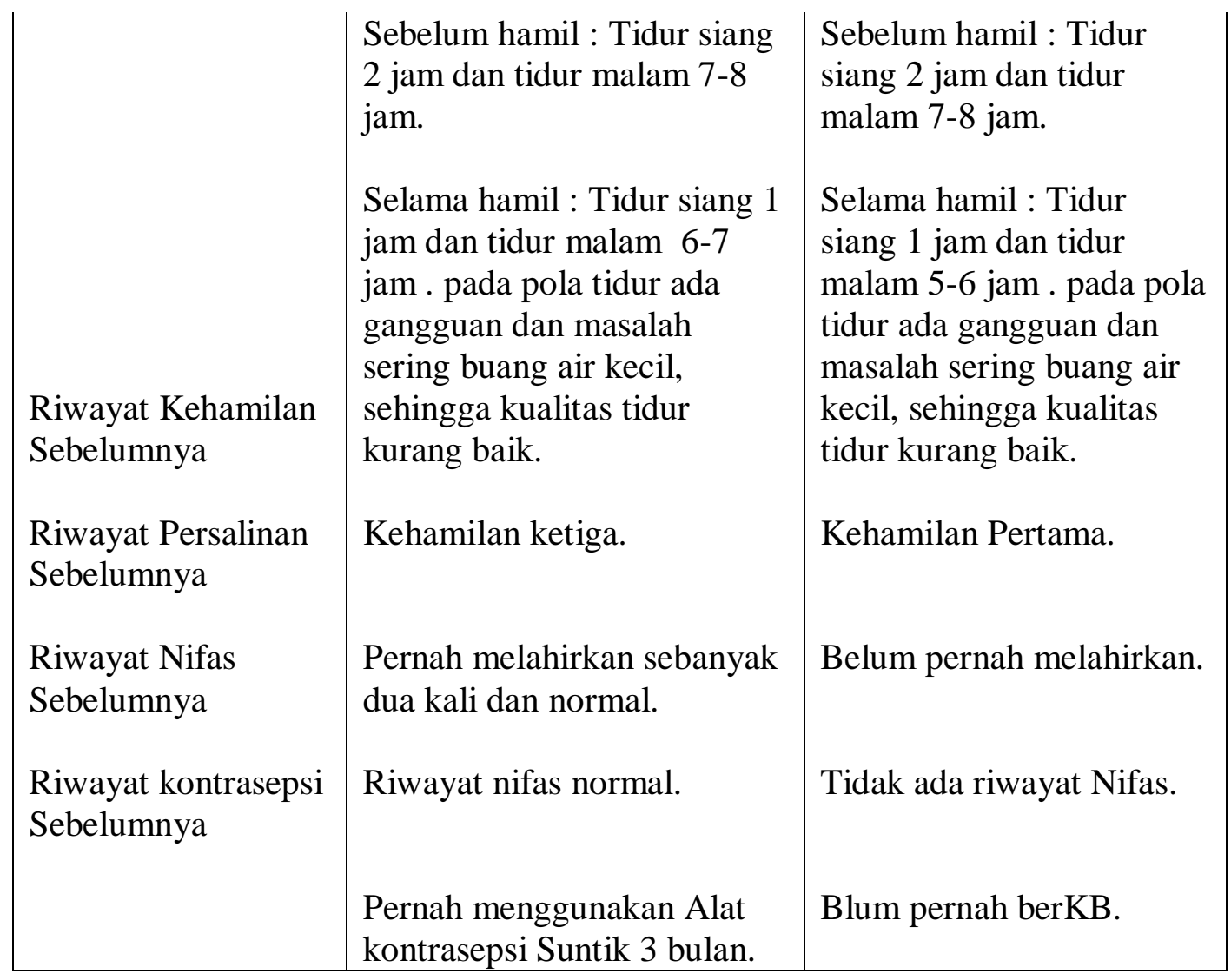

\section{2) Hasil Observasi dan Pemeriksaan Fisik}

\begin{tabular}{|l|l|l|}
\hline Observasi & Kasus I & Kasus II \\
\hline Keadaan umum & Baik & Baik \\
TD & $110 / 70 \mathrm{mmhg}$ & $90 / 60 \mathrm{mmhg}$ \\
$\mathrm{S}$ & $36^{\circ} \mathrm{C}$ & $36,5^{\circ} \mathrm{C}$ \\
$\mathrm{N}$ & $80 \mathrm{x} / \mathrm{m}$ & $78 \mathrm{x} / \mathrm{m}$ \\
$\mathrm{P}$ & $22 \mathrm{x} / \mathrm{m}$ & $20 \mathrm{x} / \mathrm{m}$ \\
GCS & Composmentis & Composmentis \\
Antropomentri: & & \\
Tinggi badan & $160 \mathrm{~cm}$ & $164 \mathrm{~cm}$ \\
LILA & $27,5 \mathrm{~cm}$ & $25,1 \mathrm{~cm}$ \\
Berat badan & $68 \mathrm{~kg}$ & $53 \mathrm{~kg}$ \\
Kenaikan BB Hamil & $8 \mathrm{~kg}$ & $5 \mathrm{~kg}$ \\
BB sebelum Hamil & $50 \mathrm{~kg}$ & $47 \mathrm{~cm}$ \\
& & \\
\hline Pemeriksaan Fisik & & Rambut bersih, tidak rontok, \\
Kepala & & tidak ada benjolan dan tidak \\
& Rambut bersih, tidak rontok, & ada nyeri tekan. \\
\hline
\end{tabular}




\begin{tabular}{|c|c|c|}
\hline Wajah & $\begin{array}{l}\text { Ada closma gravidarum, } \\
\text { tidak ada edema dan tidak } \\
\text { asa nyeri tekan. } \\
\text { Simetris, konjungtiva merah } \\
\text { muda, sclera putih bersih, } \\
\text { tidak ada sekret. }\end{array}$ & $\begin{array}{l}\text { Tidak ada closma } \\
\text { gravidarum, tidak ada } \\
\text { edema dan tidak asa nyeri } \\
\text { tekan. } \\
\text { Simetris, konjungtiva merah } \\
\text { muda, sclera putih bersih, } \\
\text { tidak ada sekret. }\end{array}$ \\
\hline $\begin{array}{l}\text { Hidung } \\
\text { Mulut/gigi }\end{array}$ & $\begin{array}{l}\text { Bersih dan tidak ada nyeri } \\
\text { tekan. }\end{array}$ & $\begin{array}{l}\text { Bersih dan tidak ada nyeri } \\
\text { tekan. }\end{array}$ \\
\hline Telinga & $\begin{array}{l}\text { Tidak sariwanan, gigi } \\
\text { kurang, bibir lebab dan } \\
\text { caries. } \\
\text { Simetris, tidak ada serumen, }\end{array}$ & $\begin{array}{l}\text { Tidak sariawan, gigi utuh, } \\
\text { bibir lembab, dan tidak } \\
\text { caries. }\end{array}$ \\
\hline Leher & $\begin{array}{l}\text { tidak ada nyeri tekan. } \\
\text { Tidak ada pembesaran }\end{array}$ & $\begin{array}{l}\text { Simetris, tidak ada serumen, } \\
\text { tidak ada nyeri tekan. }\end{array}$ \\
\hline Payudara & $\begin{array}{l}\text { kelenjar tyroid, limfe, dan } \\
\text { pembengkakan vena } \\
\text { jugularis. }\end{array}$ & $\begin{array}{l}\text { Tidak ada pembesaran } \\
\text { kelenjar tyroid, limfe, dan } \\
\text { pembengkakan } \\
\text { jugularis. }\end{array}$ \\
\hline Abdomen & $\begin{array}{l}\text { Simetris kiri dan kanan, } \\
\text { puting susu menonjol, tidak } \\
\text { ada benjolan, tidak ada } \\
\text { nyeri tekan. }\end{array}$ & $\begin{array}{l}\text { Simetris kiri dan kanan, } \\
\text { puting susu menonjol, tidak } \\
\text { ada benjolan, tidak ada nyeri } \\
\text { tekan. }\end{array}$ \\
\hline $\begin{array}{l}\text { Palpasi: } \\
\text { TFU } \\
\text { Tonus Otot } \\
\text { Striae }\end{array}$ & $\begin{array}{l}\text { Tidak ada bekas luka } \\
\text { opreasi, nampak linea nigra } \\
\text { dan strieAlbicans. }\end{array}$ & $\begin{array}{l}\text { Tidak ada bekas luka } \\
\text { opreasi, } \\
\text { nampak strieAlbicans. }\end{array}$ \\
\hline Leopold I & $\begin{array}{l}31 \mathrm{~cm} \\
\text { Kendor } \\
\text { Livide dan Linea nigra. }\end{array}$ & $\begin{array}{l}29 \mathrm{~cm} \\
\text { Tegang }\end{array}$ \\
\hline & $\begin{array}{l}\text { Teraba lunak dan tidak } \\
\text { melenting pada fundus. } \\
\text { Teraba datar memanjang }\end{array}$ & $\begin{array}{l}\text { Livide } \\
\text { Teraba lunak dan tidak } \\
\text { melenting pada fundus. }\end{array}$ \\
\hline Leopold III & $\begin{array}{l}\text { dan ada tahanan pada sisi } \\
\text { kanan perut ibu dan teraba } \\
\text { bagian-bagian terkecil dari } \\
\text { janin disisi kiri perut ibu. }\end{array}$ & $\begin{array}{l}\text { Teraba datar memanjang } \\
\text { dan ada tahanan pada sisi } \\
\text { kanan perut ibu dan teraba } \\
\text { bagian-bagian terkecil dari }\end{array}$ \\
\hline
\end{tabular}




\begin{tabular}{|c|c|c|}
\hline & & janin disisi kiri perut ibu. \\
\hline $\begin{array}{l}\text { Leopold IV } \\
\text { DJJ }\end{array}$ & $\begin{array}{l}\text { Teraba bagian bulat, keras, } \\
\text { melenting pada bagian } \\
\text { bawah perut ibu. }\end{array}$ & $\begin{array}{l}\text { Teraba bagian bulat, keras, } \\
\text { melenting pada bagian } \\
\text { bawah perut ibu. }\end{array}$ \\
\hline TBJ & Divergen $5 / 5$ & Divergen $4 / 5$ \\
\hline $\mathrm{TP}$ & 140x/menit & $135 \mathrm{x} /$ menit \\
\hline Ekstremitas Atas & 3100 gram & 2,790 gram \\
\hline Ekstremitas Bawah & 27-06-2018 & 08-07-2018 \\
\hline \multirow{3}{*}{ Genetilia } & $\begin{array}{l}\text { Tidak ada varices, tidak ada } \\
\text { oedama, Refleks patella (+). }\end{array}$ & $\begin{array}{l}\text { Tidak ada varices, tidak ada } \\
\text { oedama, Refleks patella (+) }\end{array}$ \\
\hline & $\begin{array}{l}\text { Tidak ada varices, tidak ada } \\
\text { odema, Refleks patella }(+) \text {. }\end{array}$ & $\begin{array}{l}\text { Tidak ada varices, tidak ada } \\
\text { odema, Refleks patella }(+) \text {. }\end{array}$ \\
\hline & $\begin{array}{l}\text { Tidak dilakukan } \\
\text { pemeriksaan. }\end{array}$ & $\begin{array}{ll}\text { Tidak } & \text { dilakukan } \\
\text { pemeriksaan } & \end{array}$ \\
\hline
\end{tabular}

\section{3) Hasil Pemeriksaan Diagnostik}

\begin{tabular}{|c|l|l|}
\hline Pemeriksaan Laboratorium & Kasus 1 & Kasus 2 \\
\hline $1 . \mathrm{Hb}$ & $11 \mathrm{gr} \%$ & $10 \mathrm{gr} \%$ \\
& & \\
\hline
\end{tabular}

\section{Langkah II : Analisis Diagnostik}

\begin{tabular}{|l|l|l|}
\hline Diagnosa & Data Fokus & Interprestasi Data \\
\hline
\end{tabular}




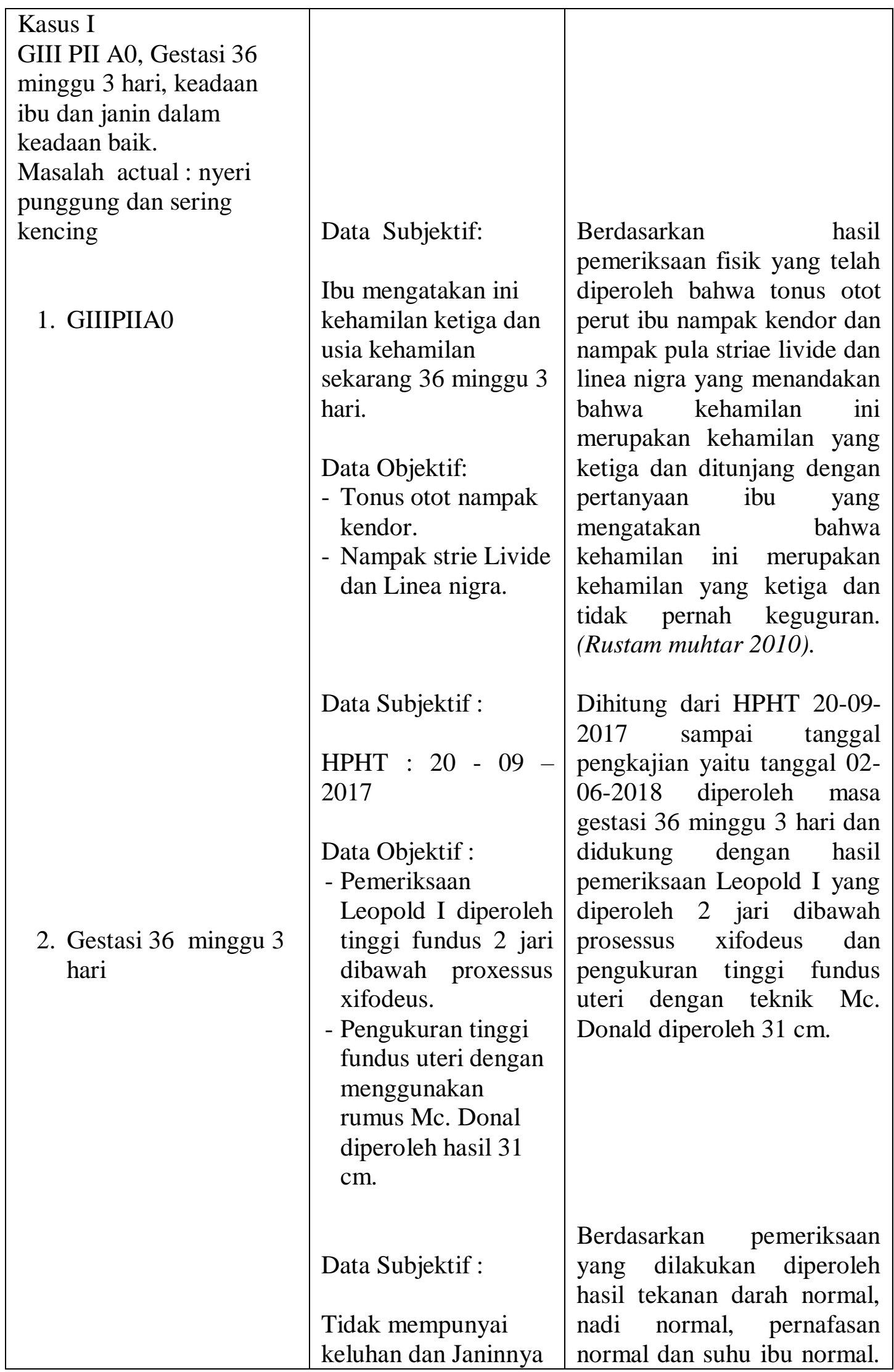




\begin{tabular}{|c|c|c|}
\hline $\begin{array}{l}\text { 3. Keadaan Ibu dan } \\
\text { Janin Baik }\end{array}$ & $\begin{array}{l}\text { bergerak kuat. } \\
\text { Data Objektif : } \\
\text { TD : } 120 / 70 \mathrm{mmHg} \\
\text { Nadi }: 82 \mathrm{x} / \mathrm{menit} \\
\mathrm{RR}: 20 \mathrm{x} / \text { menit } \\
\mathrm{S} \quad: 37,2 \mathrm{C} \\
\text { DJJ : 135x/menit } \\
\text { Payudara simetris kiri } \\
\text { kanan, putting susu } \\
\text { menonjol, tidak ada } \\
\text { benjolan dan nyeri } \\
\text { tekan. }\end{array}$ & $\begin{array}{l}\text { Ini merupakan kondisi ibu } \\
\text { dalam keadaan baik dan } \\
\text { tidak ada keluhan dalam } \\
\text { kehamilannya. } \\
\text { (Obstetric fisiologis). } \\
\text { Dan pemeriksaan DJJ sifat } \\
\text { bunyi jantung ini } \\
\text { dihubungkan dengan tekanan } \\
\text { intra uterin untuk } \\
\text { mendengarkan ada tidaknya } \\
\text { bunyi jantung dan } \\
\text { didapatkan hasil DJJ ibu } \\
\text { normal dimana DJJ normal } \\
\text { yaitu 120-160x/menit secara } \\
\text { teratur. }\end{array}$ \\
\hline $\begin{array}{l}\text { Kasus } 2 \\
\text { GI P0 A0, Gestasi } 34 \\
\text { minggu } 6 \text { hari, Keadaan } \\
\text { Ibu dan Janin dalam } \\
\text { keadaan baik. } \\
\text { Masalah actual : nyeri } \\
\text { punggung }\end{array}$ & $\begin{array}{l}\text { Data Subjektif : } \\
\text { ini merupakan } \\
\text { kehamilan pertama } \\
\text { dan tidak pernah } \\
\text { mengalami } \\
\text { keguguran. } \\
\text { Data Objektif : } \\
\text { Tonus otot Nampak } \\
\text { tegang } \\
\text { Nampak striae Livide } \\
\text { Data subjektif : } \\
\text { HPHT 01 - } 10 \text { - } 2017 \\
\text { Data Objektif }\end{array}$ & $\begin{array}{l}\text { Berdasarkan hasil } \\
\text { pemeriksaan fisik yang telah } \\
\text { dilakukan diperoleh bahwa } \\
\text { tonus otot perut ibu Nampak } \\
\text { tegang dan nampak pula } \\
\text { striae livide yang } \\
\text { menandakan bahwa } \\
\text { kehamilan ini merupakan } \\
\text { kehamilan yang pertama } \\
\text { ditunjang dengan pertanyaan } \\
\text { ibu yang mengatakan bahwa } \\
\text { kehamilan ini merupakan } \\
\text { kehamilan yang pertama dan } \\
\text { tidak pernah keguguran } \\
\text { Rustam Muhtar 2010). } \\
\text { Di hitung mulai dari HPHT } \\
\text { 01-10-2017 sampai tanggal } \\
\text { pengkajian yaitu tanggal 02- } \\
\text { 06-2018 diperoleh masa }\end{array}$ \\
\hline
\end{tabular}




\begin{tabular}{|c|c|c|}
\hline $\begin{array}{l}\text { 3. Keadaan Ibu dan } \\
\text { Janin }\end{array}$ & 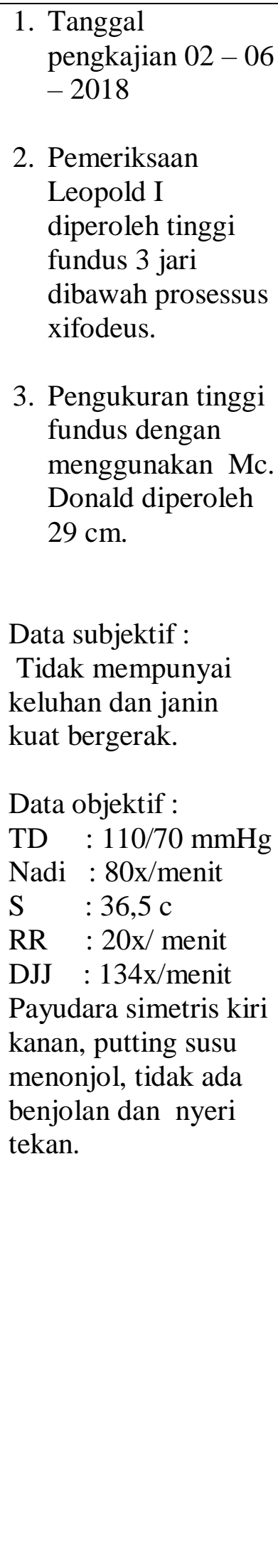 & $\begin{array}{l}\text { Berdasarkan pemeriksaan } \\
\text { yang dilakukan diperoleh } \\
\text { hasil tekanan darah normal, } \\
\text { nadi normal, pernafasan } \\
\text { normal dan suhu ibu normal. } \\
\text { Ini merupakan kondisi ibu } \\
\text { dalam keadaan baik dan } \\
\text { tidak ada keluhan dalam } \\
\text { kehamilannya. } \\
\text { ( Obstetric fisiologis). } \\
\text { Dan pemeriksaan DJ sifat } \\
\text { bunyi jantung ini } \\
\text { dihubungkan dengan tekanan } \\
\text { intra uterin untuk } \\
\text { mendengarkan ada tidaknya } \\
\text { bunyi jantung dan }\end{array}$ \\
\hline
\end{tabular}




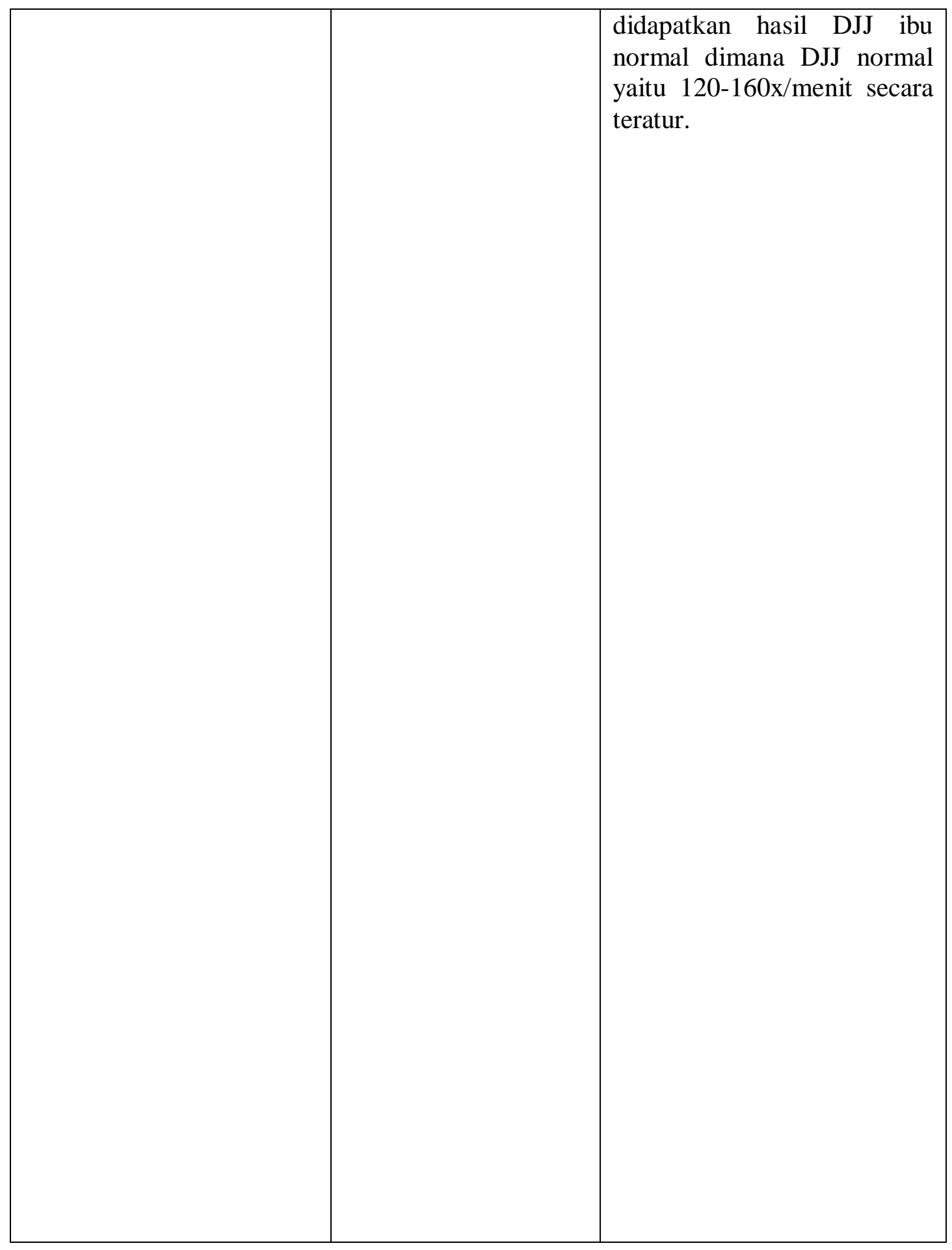




\section{Langkah III Diagnosa Masalah Potensial}

\section{Analisa Data/ Masalah potensial}

Kasus 1

GIIIPIIAO : Tidak ada data yang mendukung

Kasus 2

GIPOAO : Tidak ada data yang mendukung

\section{Langkah VI Tindakan Segera}

Kasus 1 : Tidak ada data yang menunjang

Kasus 2 : Tidak ada data yang menunjang

\section{Langkah V Perencanaan}

\begin{tabular}{|c|c|c|}
\hline Tujuan & Kriteria Hasil & Perencanaan dan Rasional \\
\hline $\begin{array}{l}\text { Kasus } 1 \\
\text { Sering buang air } \\
\text { kecil dan nyeri } \\
\text { punggung sudah } \\
\text { teratasi }\end{array}$ & $\begin{array}{l}\text { Keadaan Umum : Baik } \\
\text { TTV } \\
\text { TD : Sistole } 110-130 \\
\\
\quad \text { Diastole } 60-100 \\
\mathrm{~N} \quad: 60-80 x / \text { menit } \\
\mathrm{P} \quad: 16-24 \mathrm{x} / \text { menit } \\
\mathrm{S} \quad: 36,5-37,5 \mathrm{c}\end{array}$ & $\begin{array}{l}\text { 1. Jalin komunikasi } \\
\text { terpautik. Rasional : } \\
\text { menanamkan kepercayaan } \\
\text { pasien kepada petugas } \\
\text { kesehatan. (Saifuddin, 2010). } \\
\text { 2. Berikan dukungan } \\
\text { emosional kepada ibu dalam } \\
\text { menghadapi dan merawat } \\
\text { kehamilannya. } \\
\text { Rasional : dukungan yang } \\
\text { diberikan dapat menambah } \\
\text { rasa percaya diri ibu. } \\
\text { 3. } \\
\text { untuk melakukan senam } \\
\text { hamil. } \\
\text { Rasional: untuk membantu } \\
\text { mengurangi nyeri } \\
\text { punggung(Dewi Vivian Lia, } \\
\text { 2011). }\end{array}$ \\
\hline
\end{tabular}




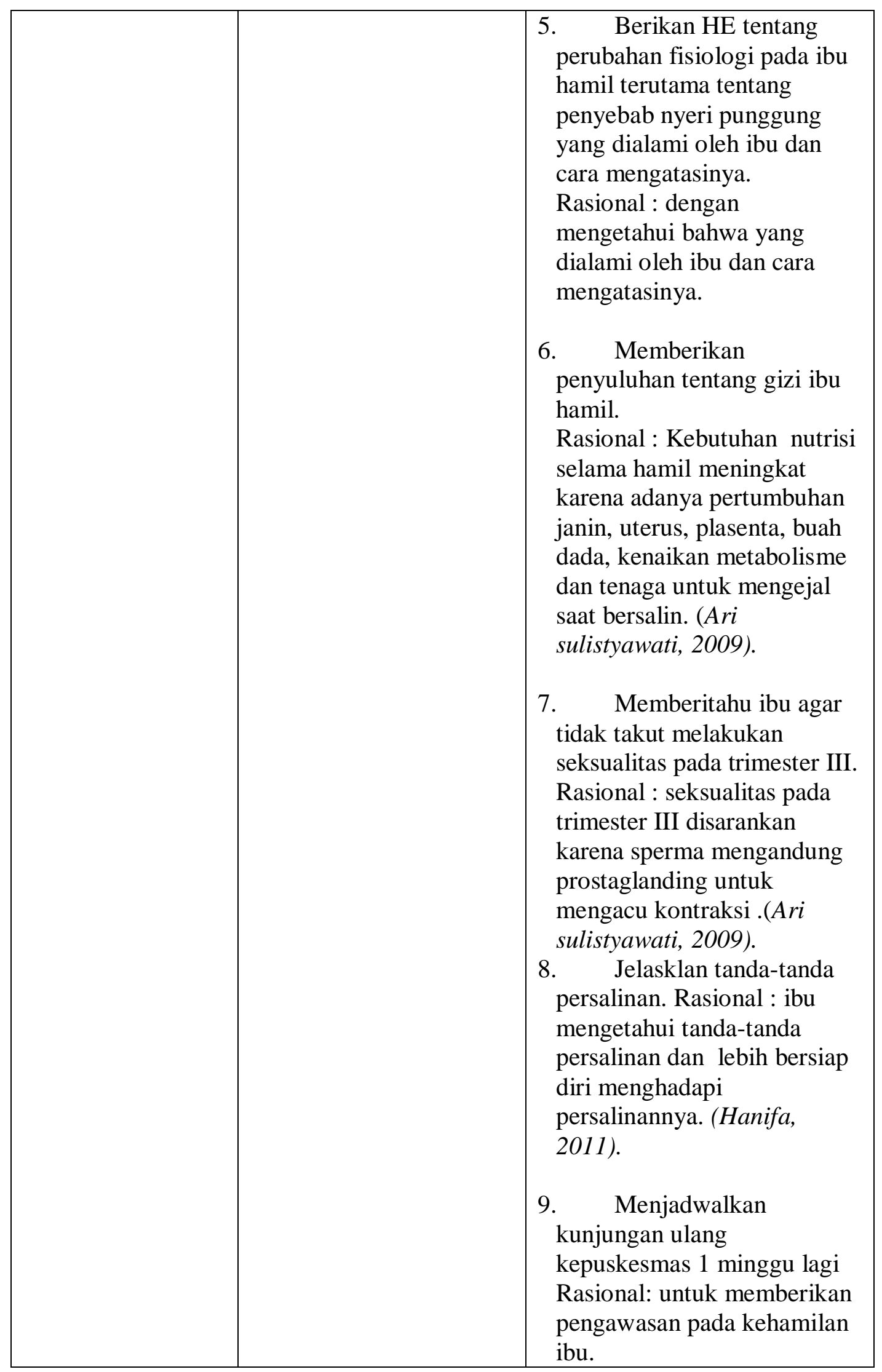




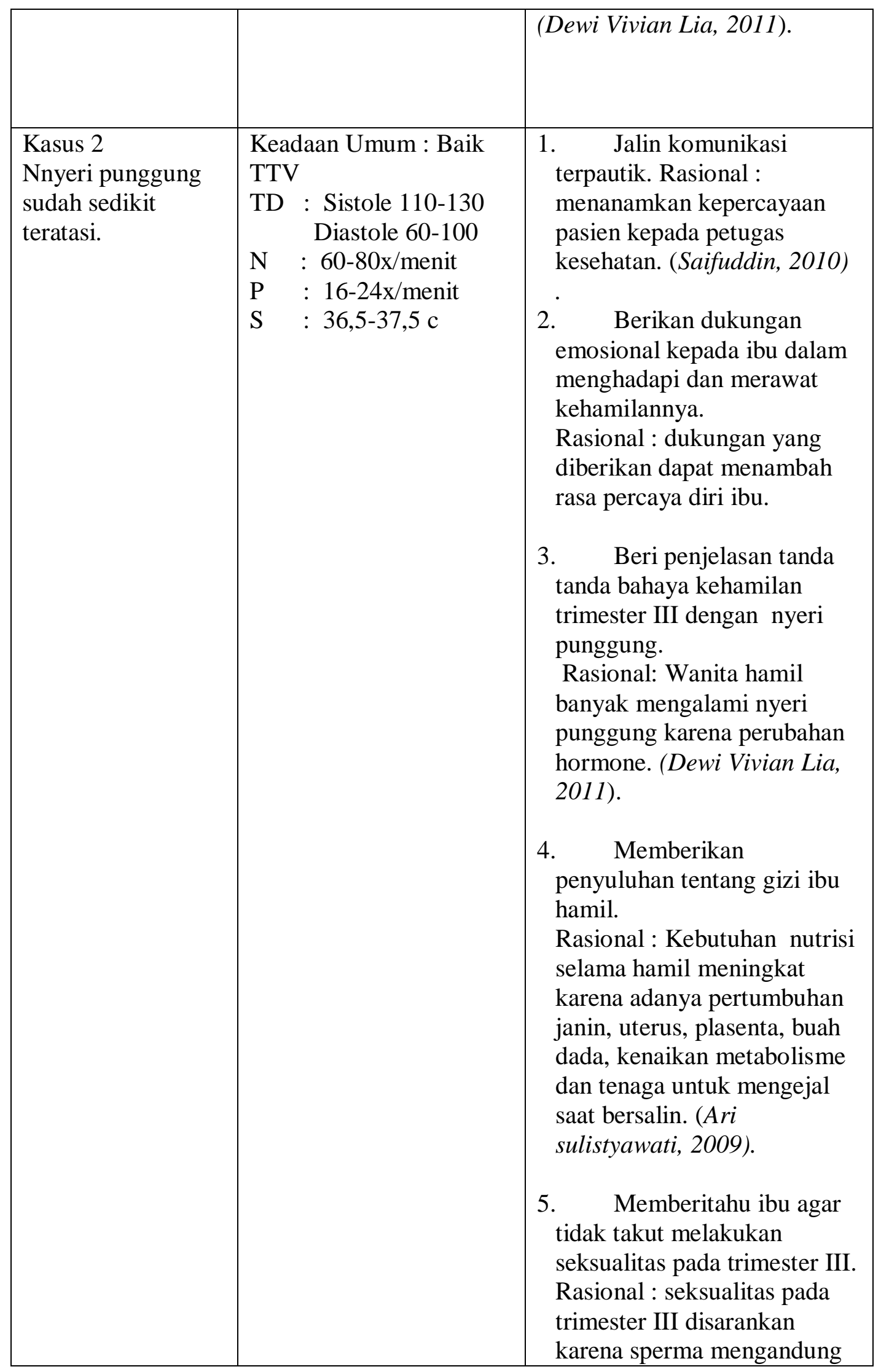




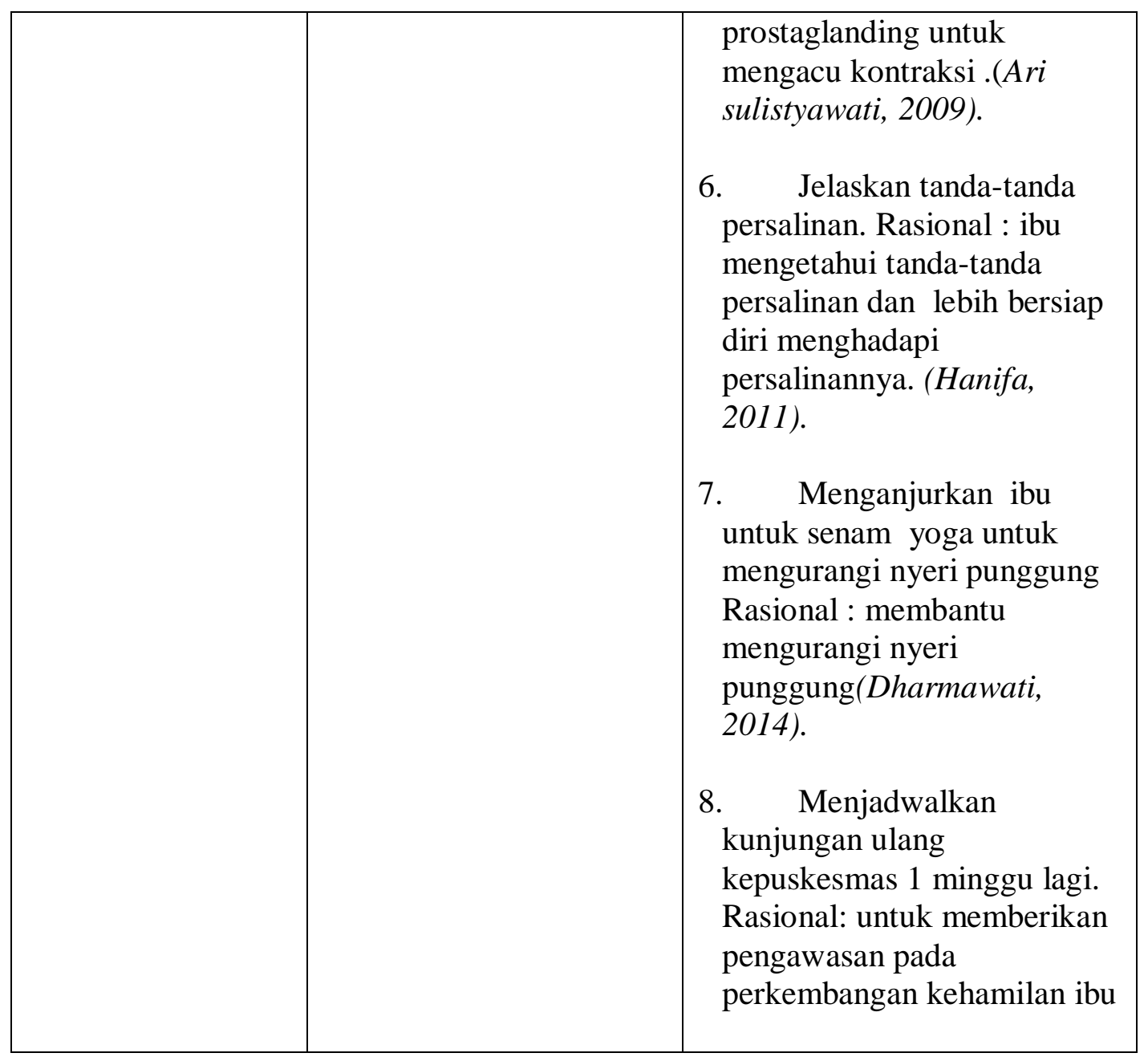

\begin{tabular}{|c|c|c|}
\hline Penatalaksanaan & Kasus 1 & Kasus 2 \\
\hline \multirow{4}{*}{$\begin{array}{l}\text { Sabtu 02-06- } \\
2018\end{array}$} & Pukul 14.30. wita & Pukul 15.00.wita \\
\hline & $\begin{array}{l}\text { 1. Tetap menjalin } \\
\text { komunikasi yang baik } \\
\text { dengan pasien maupun } \\
\text { keluarganya. } \\
\text { Hasil : Ibu mengerti. }\end{array}$ & $\begin{array}{l}\text { 1. Tetap menjalin } \\
\text { komunikasi yang baik dengan } \\
\text { pasien maupun keluarganya. } \\
\text { Hasil : Ibu mengerti. }\end{array}$ \\
\hline & $\begin{array}{l}\text { 2. Memberikan } \\
\text { informasi pada ibu tentang } \\
\text { hasil pemeriksaan bahwa } \\
\text { umur kehamilan saat ini } 36 \\
\text { minggu } 3 \text { hari dengan }\end{array}$ & $\begin{array}{l}2 . \quad \text { Anjurkan ibu untuk } \\
\text { melakukan perwatan } \\
\text { payudara. } \\
\text { Hasil : ibu mengerti dan mau } \\
\text { melakukan anjuran yang } \\
\text { diberikan. }\end{array}$ \\
\hline & $\begin{array}{l}\text { Keaaaan ibu dan janin senat. } \\
\text { Hasil : ibu senang }\end{array}$ & 3. Menganjurkan ibu \\
\hline
\end{tabular}




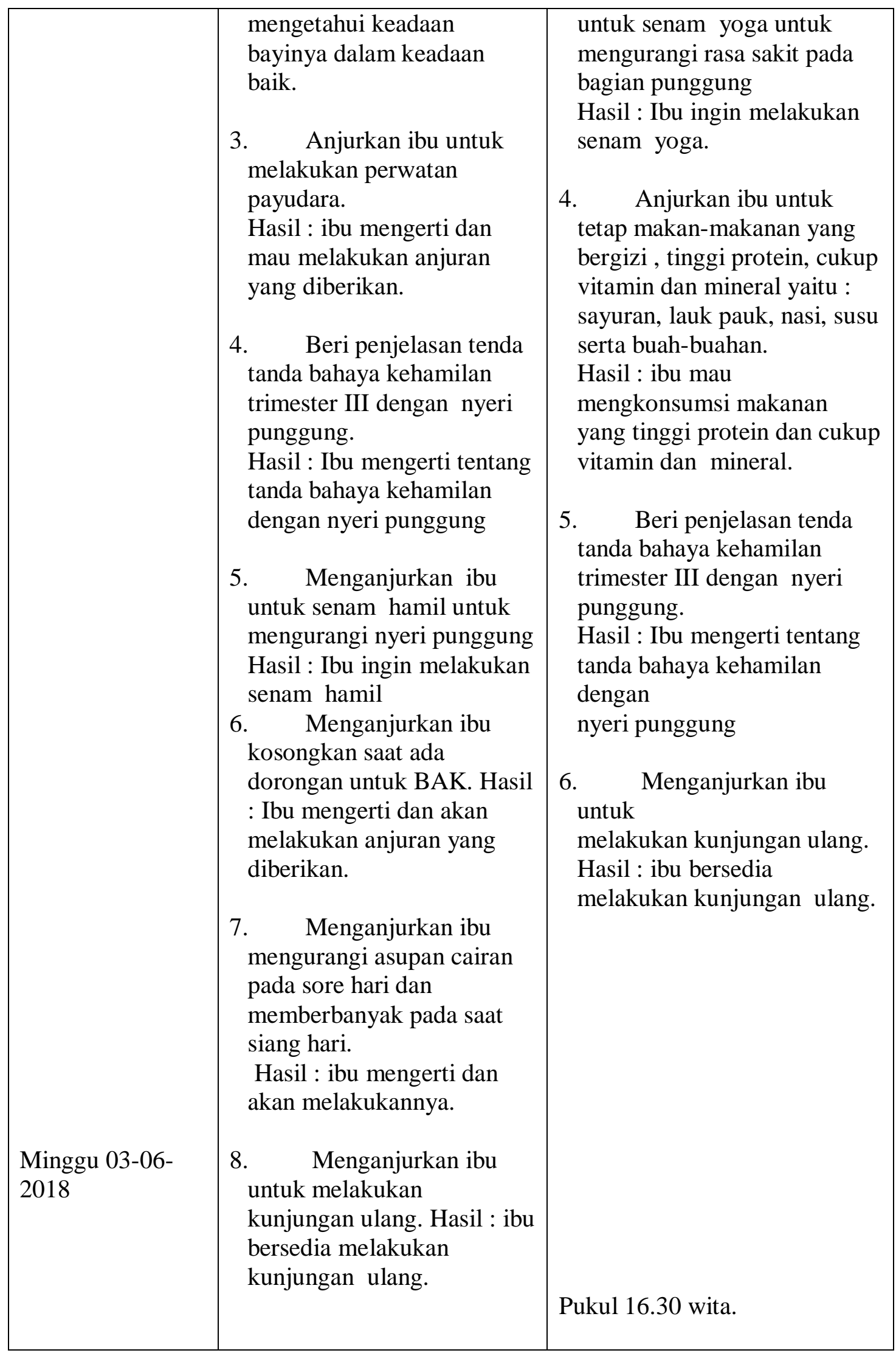




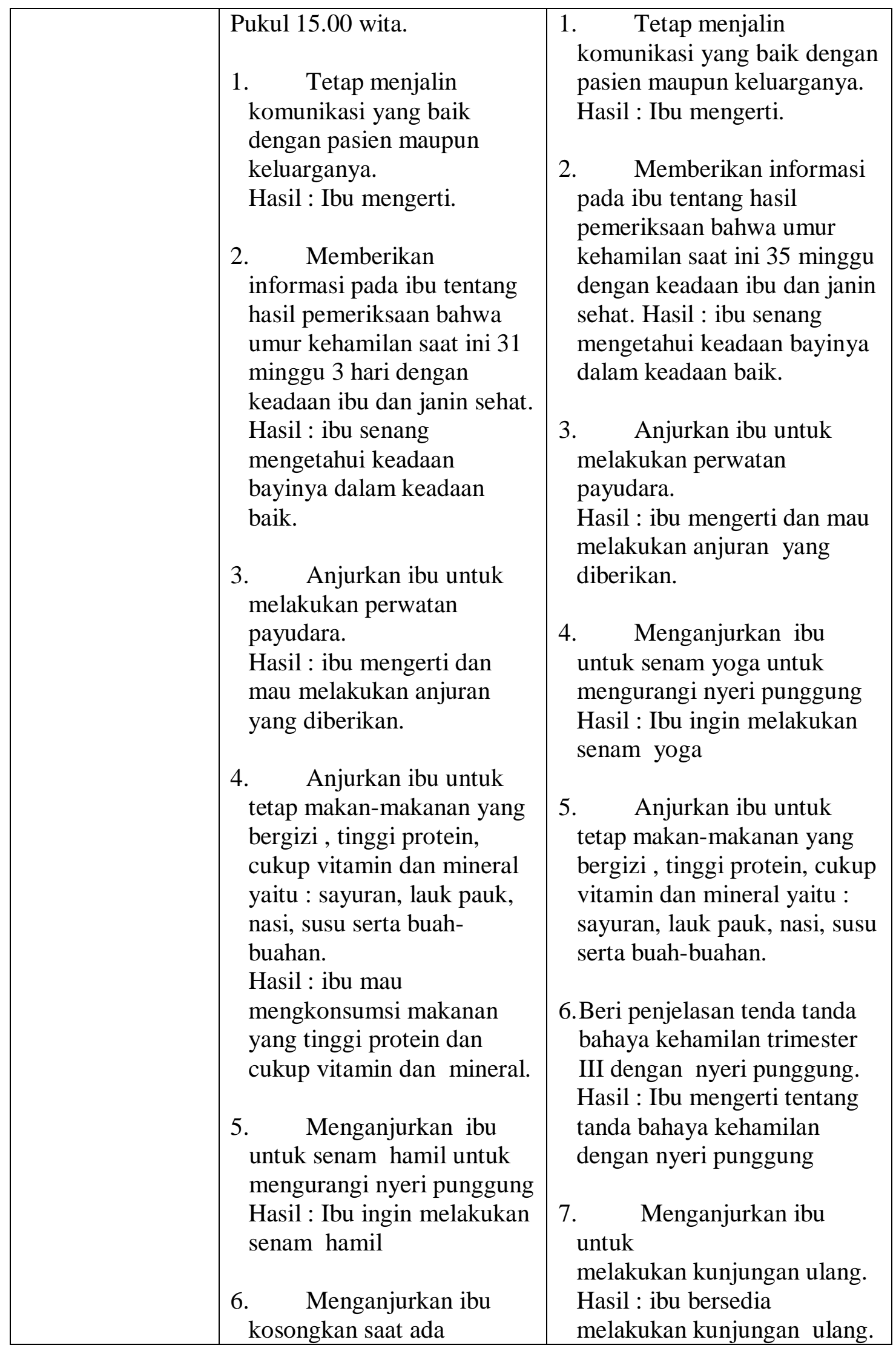




\begin{tabular}{|c|c|c|}
\hline Senin 04-06-2018 & 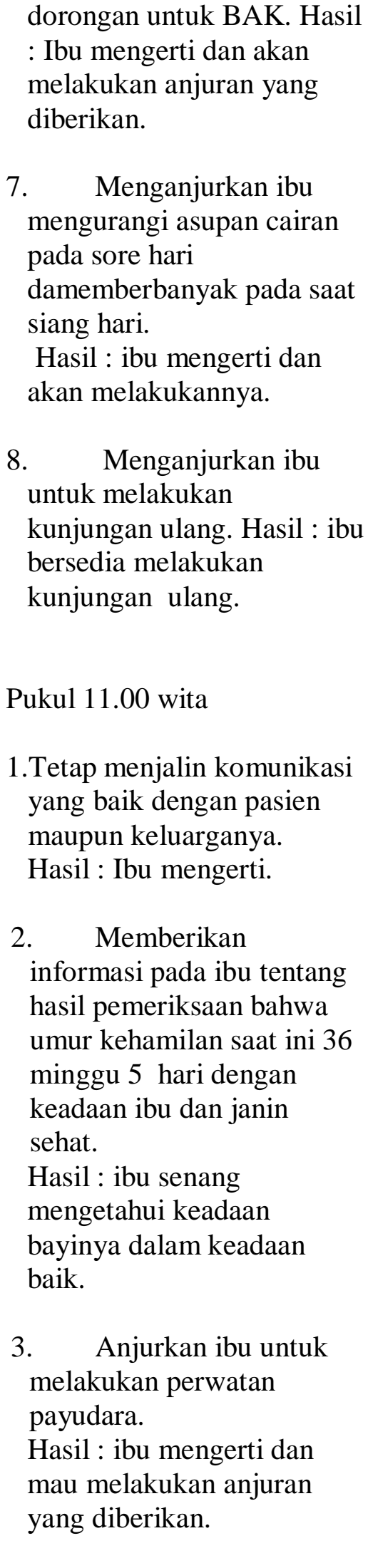 & $\begin{array}{l}\text { Pukul } 13.00 \text { wita } \\
\text { 1. Tetap menjalin komunikasi } \\
\text { yang baik dengan pasien } \\
\text { maupun keluarganya. } \\
\text { Hasil : Ibu mengerti. } \\
\text { 2. Memberikan informasi pada } \\
\text { ibutentang hasil } \\
\text { pemeriksaan bahwa umur } \\
\text { kehamilan saat ini } 35 \\
\text { minggu } 1 \text { hari } \\
\text { dengankeadaan ibu dan janin } \\
\text { sehat. } \\
\text { Hasil : ibu senang } \\
\text { mengetahui keadaan bayinya } \\
\text { dalam keadaan baik. } \\
\text { 3. Anjurkan ibu untuk } \\
\text { melakukan perwatan } \\
\text { payudara. } \\
\text { Hasil : ibu mengerti dan mau } \\
\text { melakukan anjuran yang } \\
\text { diberikan. } \\
\text { 4. Menganjurkan ibu untuk } \\
\text { senam yoga untuk } \\
\text { mengurangi rasa sakit pada } \\
\text { bagian punggung } \\
\text { Hasil : Ibu ingin melakukan } \\
\text { senam yoga. } \\
\text { 5. Anjurkan ibu untuk }\end{array}$ \\
\hline
\end{tabular}


Selasa 05-062018

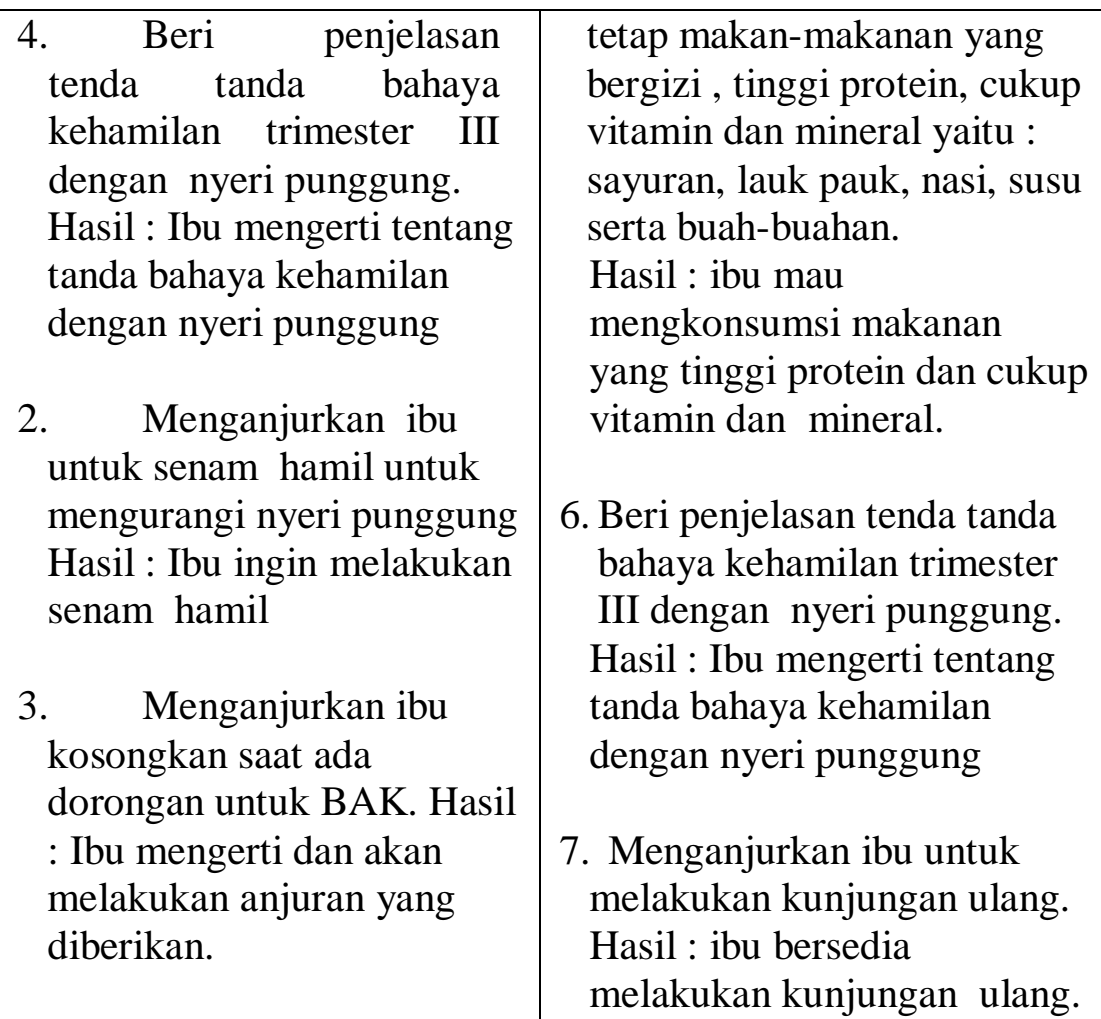

4. Menganjurkan ibu mengurangi asupan cairan pada sore hari damemberbanyak pada saat siang hari.

Hasil : ibu mengerti dan akan melakukannya.

5. Menganjurkan ibu untuk melakukan kunjungan ulang. Hasil : ibu bersedia melakukan kunjungan ulang.

Pukul 10.00 wita.

1. Tetap menjalin komunikasi yang baik dengan pasien maupun keluarganya.

Hasil : Ibu mengerti.

2. Memberikan
Pukul 14.00 wita.

1. Tetap menjalin komunikasi yang baik dengan pasien maupun keluarganya. Hasil : Ibu mengerti.

2. Memberikan informasi pada ibu tentang hasil pemeriksaan bahwa umur kehamilan saat ini 35 minggu 2 hari dengan keadaan ibu dan janin sehat. Hasil : ibu senang mengetahui keadaan bayinya dalam keadaan baik.

3. Anjurkan ibu untuk melakukan 


\begin{tabular}{|c|c|c|}
\hline Rabu 06-06-2018 & 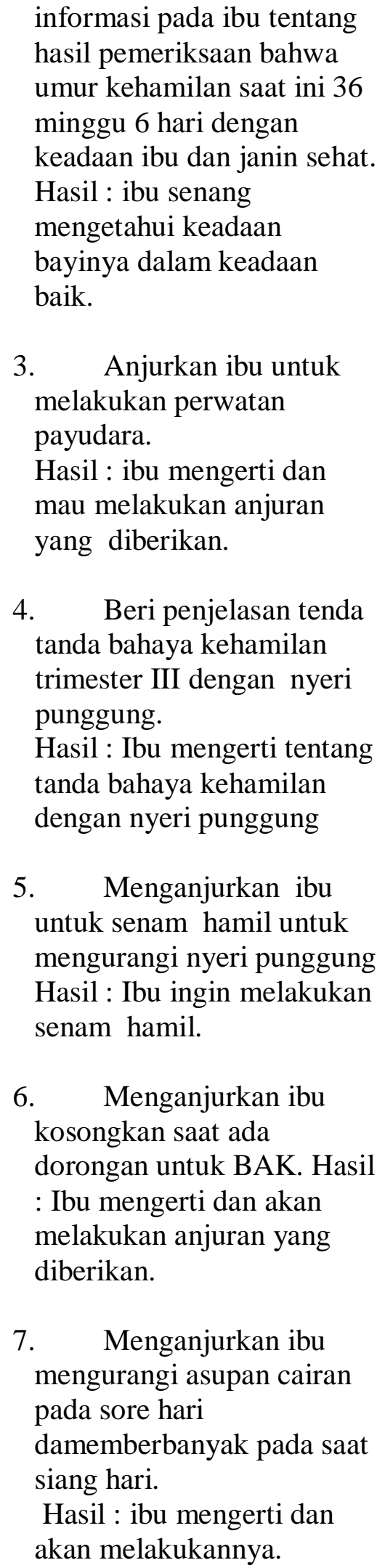 & 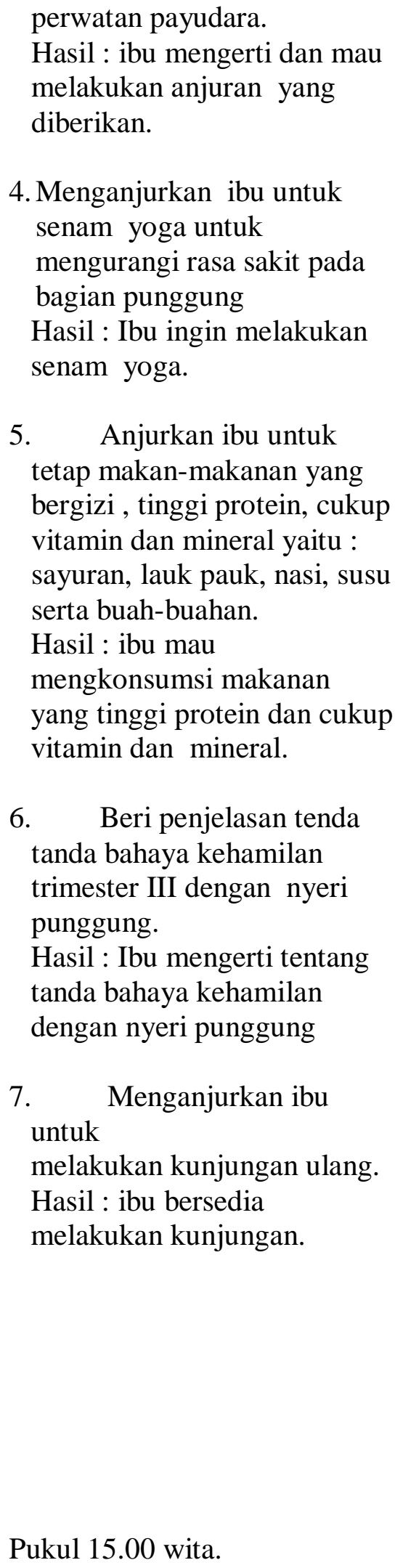 \\
\hline
\end{tabular}




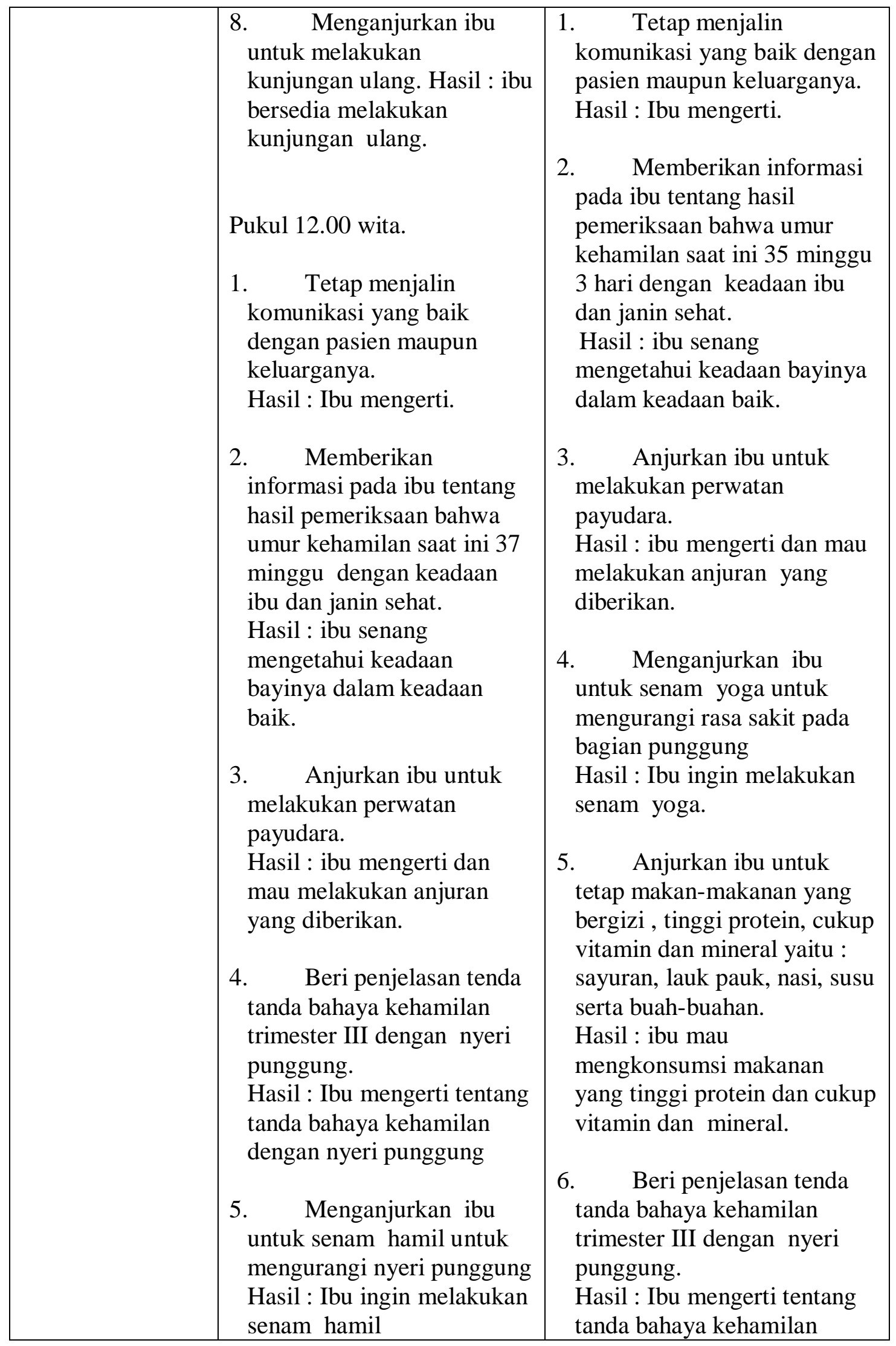




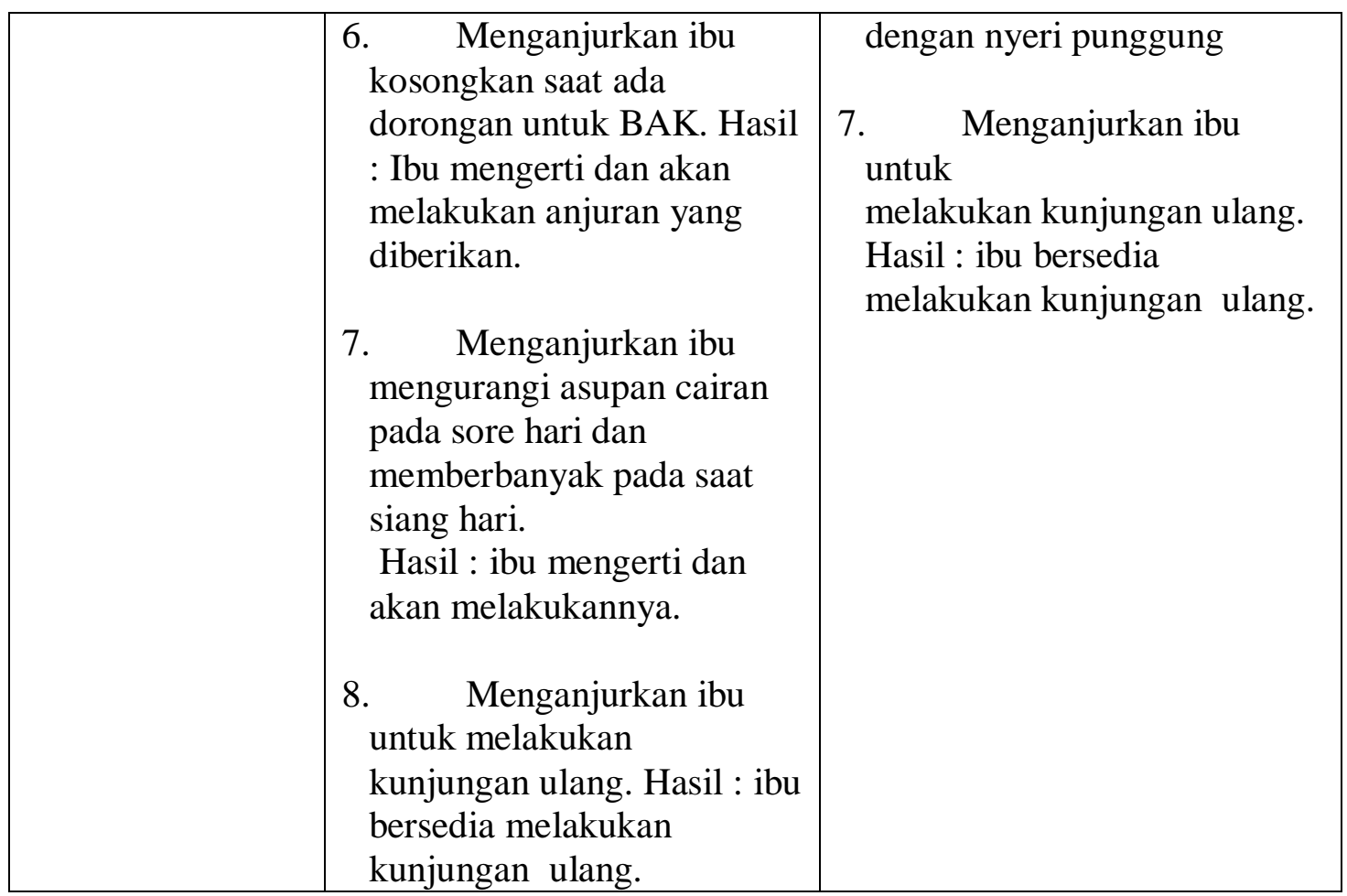

\section{Langkah VI Evaluasi}

\begin{tabular}{|c|c|c|}
\hline KASUS & HASIL & HASIL \\
\hline $\begin{array}{l}\text { Kasus } 1 \\
\text { GIIIPIIA0 }\end{array}$ & $\begin{array}{l}\text { Kehamilan ini berjalan dengan } \\
\text { normal ditandai dengan : } \\
\text { 1. Sering buang air kecil } \\
\text { ibu sudah teratasi. } \\
\text { 2. Nyeri punggung ibu } \\
\text { sudah teratasi. } \\
\text { 3. Pemeriksaan fisik normal } \\
\text { TTV : } \\
\text { TD : } 120 / 70 \mathrm{mmHg} \\
\mathrm{N} \quad: 80 \mathrm{x} / \text { menit } \\
\mathrm{P}: 20 \mathrm{x} / \text { menit } \\
\mathrm{S} \quad: 37,2 \mathrm{c}\end{array}$ & $\begin{array}{l}\text { Data Subjektif } \\
\text { Ibu mengatakan tidak } \\
\text { merasakan keluhan apapun } \\
\text { dalam kehamilannya. } \\
\text { Data Subjektif } \\
\text { TTV : } \\
\text { TD : 120/70 mmHg } \\
\quad \mathrm{N} \quad: 80 \mathrm{x} / \mathrm{menit} \\
\quad \mathrm{S} \quad: 37,2 \mathrm{c} \\
\quad \mathrm{P} \quad \text { :0x/menit } \\
\text { Analisa } \\
\text { GIIIPIIA0, Gestasi } 37 \text { minggu } \\
4 \text { hari, keadaan ibu dan janin } \\
\text { baik. } \\
\text { Penatalaksanaan } \\
\text { Tanggal 02-06-2018 } \\
\text { Pukul.14.30 wita. } \\
\text { 1. Tetap menjalin } \\
\text { komunikasi yang baik dengan }\end{array}$ \\
\hline
\end{tabular}




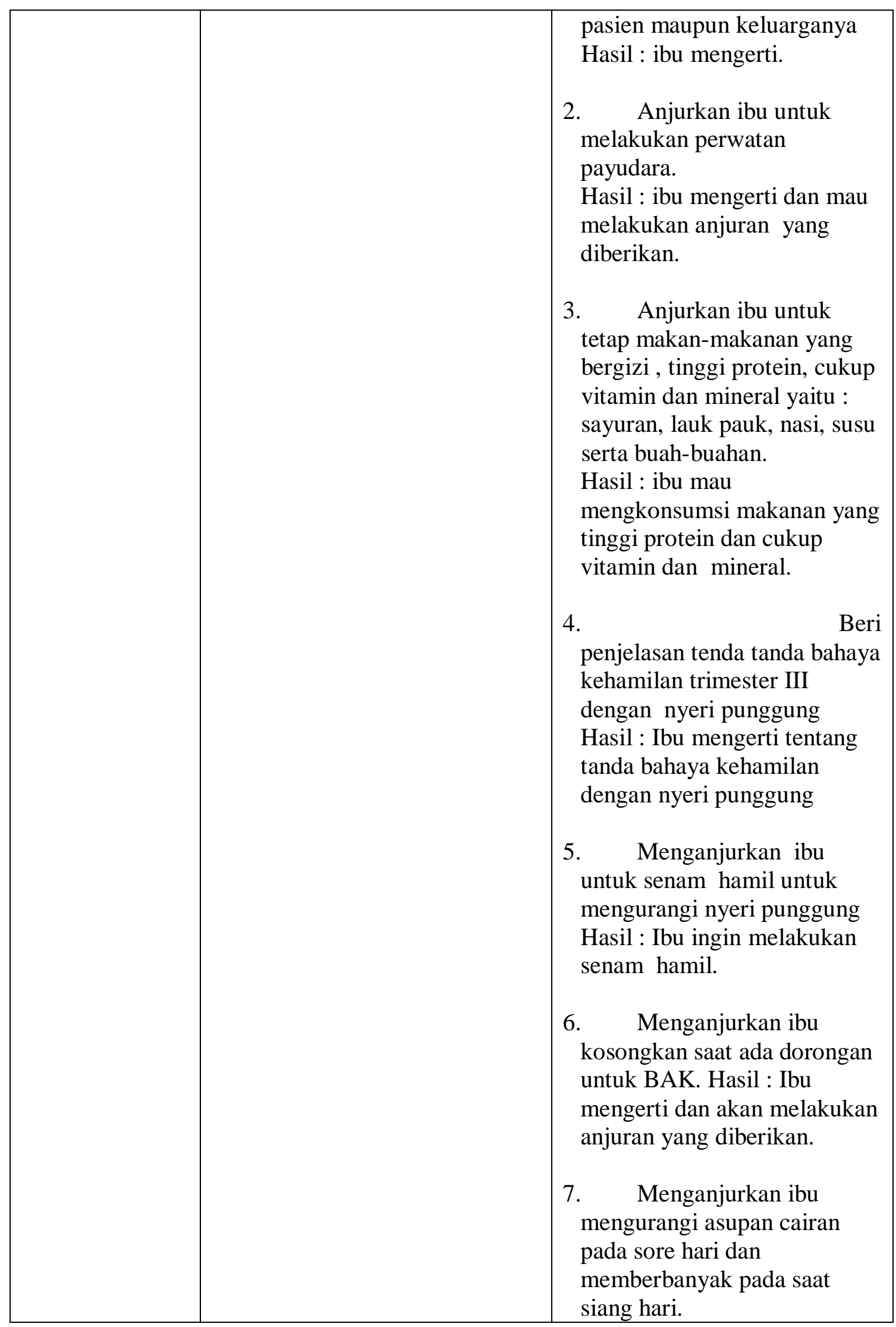




\begin{tabular}{|c|c|c|}
\hline & & $\begin{array}{l}\text { Hasil : ibu mengerti dan akan } \\
\text { melakukannya. } \\
\text { 8. Menganjurkan ibu } \\
\text { untuk melakukan kunjungan } \\
\text { ulang. Hasil : ibu bersedia } \\
\text { melakukan kunjungan ulang. }\end{array}$ \\
\hline $\begin{array}{l}\text { Kasus } 2 \\
\text { GIP0A0 }\end{array}$ & $\begin{array}{l}\text { 1. Kehamilan ini berjalan } \\
\text { dengan normal ditandai } \\
\text { dengan : } \\
2 . \quad \text { Nyeri punggung ibu } \\
\text { sudah mulai teratasi. } \\
\text { 3. Pemeriksaan fisik normal } \\
\text { TTV : } \\
\text { TD : } 110 / 70 \mathrm{mmHg} \\
\mathrm{N}: 80 \mathrm{x} / \text { menit } \\
\mathrm{P}: 20 \mathrm{x} / \text { menit } \\
\mathrm{S}: 36 \mathrm{c}\end{array}$ & $\begin{array}{l}\text { Data Subjektif } \\
\text { Ibu mengatakan tidak } \\
\text { merasakan keluhan apapun } \\
\text { dalam kehamilannya. } \\
\text { Data Subjektif } \\
\text { TTV: } \\
\quad \text { TD : 110/70 mmHg } \\
\quad \mathrm{N} \quad \text { : 80x/menit } \\
\quad \text { S } \quad 36 \mathrm{c} \\
\quad \text { P } 20 x / \text { menit } \\
\text { Analisa } \\
\text { GI0IA0, Gestasi } 31 \text { minggu } 2 \\
\text { hari, keadaan ibu dan janin } \\
\text { baik. } \\
\text { Penatalaksanaan } \\
\text { Tanggal 02- 06 - 2018. Pukul } \\
\text { 15.30 wita } \\
\text { 1. Tetap menjalin } \\
\text { komunikasi yang baik dengan } \\
\text { pasien maupun keluarganya. } \\
\text { Hasil : Ibu mengerti. } \\
\text { 2. Anjurkan ibu untuk } \\
\text { melakukan perwatan } \\
\text { payudara. } \\
\text { Hasil : ibu mengerti dan mau } \\
\text { melakukan anjuran yang } \\
\text { diberikan. }\end{array}$ \\
\hline & & $\begin{array}{l}\text { 3. Menganjurkan ibu } \\
\text { untuk senam yoga untuk } \\
\text { mengurangi nyeri punggung. } \\
\text { Hasil : Ibu ingin melakukan } \\
\text { senam yoga. }\end{array}$ \\
\hline
\end{tabular}




\begin{tabular}{|c|}
\hline $\begin{array}{l}\text { 4. } \quad \text { Anjurkan ibu untuk } \\
\text { tetap makan-makanan yang } \\
\text { bergizi , tinggi protein, cukup } \\
\text { vitamin dan mineral yaitu : } \\
\text { sayuran, lauk pauk, nasi, susu } \\
\text { serta buah-buahan. } \\
\text { Hasil : ibu mau } \\
\text { mengkonsumsi makanan yang } \\
\text { tinggi protein dan cukup } \\
\text { vitamin dan mineral. } \\
\text { 5. Beri } \\
\text { penjelasan tenda tanda bahaya } \\
\text { kehamilan trimester III } \\
\text { dengan nyeri punggung } \\
\text { Hasil : Ibu mengerti tentang } \\
\text { tanda bahaya kehamilan } \\
\text { dengan nyeri punggung } \\
\text { Menganjurkan ibu } \\
\text { 6. } \\
\text { untuk istirahat yang cukup } \\
\text { Hasil : ibu mengerti dan akan } \\
\text { memperhatikan pola } \\
\text { istirahatmya. } \\
\text { 7. Menganjurkan ibu } \\
\text { untuk } \\
\text { melakukan kunjungan ulang. } \\
\text { Hasil : ibu bersedia } \\
\text { melakukan kunjungan ulang. }\end{array}$ \\
\hline
\end{tabular}

\section{CATATAN PERKEMBANGAN}

\begin{tabular}{|l|l|l|}
\hline $\begin{array}{c}\text { Catatan } \\
\text { Perkembangan }\end{array}$ & Tanggal 07 -06 - 2018 \\
\hline Kasus 1 & $\begin{array}{l}\text { Data Subjektif }(\text { S }) \\
\text { Sering buang air kecil. } \\
\text { Sering nyeri punggung. }\end{array}$ & $\begin{array}{l}\text { Data Subjektif }(\text { S }) \\
\text { Ibu mengatakan nyeri punggung } \\
\text { sudah sedikit teratasi. }\end{array}$ \\
& $\begin{array}{l}\text { Data Objektif }(\boldsymbol{O}) \\
\text { TFU 2 jari dibawah prosessus } \\
\text { xifodeus . }\end{array}$ & $\begin{array}{l}\text { Data Objektif }(\boldsymbol{O}) \\
\text { TFU 2 jari dibawah prosessus } \\
\text { xifodeus. }\end{array}$ \\
\hline
\end{tabular}




\begin{tabular}{|c|c|}
\hline $\begin{array}{l}\text { Nampak linea nigra dan striae } \\
\text { Albicalis } \\
\text { TTV : } \\
\text { TD }: 120 / 70 \mathrm{mmHg} \\
\mathrm{N}: 80 \mathrm{x} / \mathrm{menit} \\
\mathrm{S}: 37 \mathrm{C} \\
\mathrm{P}: 20 \mathrm{x} / \text { menit }\end{array}$ & $\begin{array}{l}\text { Nampak linea nigra dan striae } \\
\text { Albicalis } \\
\text { TTV : } \\
\text { TD : 120/70 mmHg } \\
\mathrm{N}: \text { : 80x/menit } \\
\mathrm{S}: 37 \mathrm{C} \\
\mathrm{P} \quad \text { : 20x/ menit } \\
\text { Analisa (A) } \\
\text { GIIIPIIA0, Gestasi } 37 \text { minggu } 4 \\
\text { hari. Keadaan ibu dan janin baik. } \\
\\
\text { Penatalaksanaan (P) } \\
\text { Tanggal 07-06 - 2018. Pukul } \\
\text { 15.00 wita. } \\
\text { 1. Tetap menjalin komunikasi } \\
\text { yang baik dengan pasien } \\
\text { maupun keluarganya. } \\
\text { Hasil : Ibu mengerti. } \\
\text { 2. Melakukan pengukuran TFU } \\
\text { Hasil : } 2 \text { jari dibawah } \\
\text { prosessus xideus. } \\
\text { 3. Menganjurkan ibu untuk } \\
\text { senam hamil untuk } \\
\text { mengurangi nyeri punggung. } \\
\text { Hasil : Ibu ingin melakukan } \\
\text { senam hamil. } \\
\text { Menganjurkan ibu } \\
\text { kosongkan saat ada dorongan } \\
\text { untuk BAK. Hasil : Ibu } \\
\text { mengerti dan akan melakukan } \\
\text { anjuran yang diberikan. } \\
\text { 5. Menganjurkan ibu } \\
\text { mengurangi asupan cairan } \\
\text { pada sore hari dan } \\
\text { memberbanyak pada saat siang } \\
\text { hari. } \\
\text { Hasil : ibu mengerti dan akan } \\
\text { melakukannya. } \\
\text { 6. Menganjurkan ibu untuk } \\
\text { kunjungan ulang. } \\
\text { Hasil : ibu bersedia } \\
\text { ara }\end{array}$ \\
\hline
\end{tabular}




\begin{tabular}{|c|c|c|}
\hline & & melakukan kunjungan ulang. \\
\hline Kasus 2 & $\begin{array}{l}\text { Tanggal } 19-06-2108 \\
\text { Data Subjektif }(\boldsymbol{S} \\
\text { Sering merasakan nyeri pada } \\
\text { bagian punggung. } \\
\text { Data Objektif }(\boldsymbol{O}) \\
\text { TFU } 3 \text { jari dibawah prosessus } \\
\text { xifodeus . } \\
\text { Nampak strie livide } \\
\text { TTV : } \\
\text { TD : } 110 / 70 \mathrm{mmHg} \\
\mathrm{N}: 80 \mathrm{x} / \mathrm{menit} \\
\mathrm{S}: 36,5 \mathrm{C} \\
\mathrm{P}: 20 \mathrm{x} / \text { menit. }\end{array}$ & 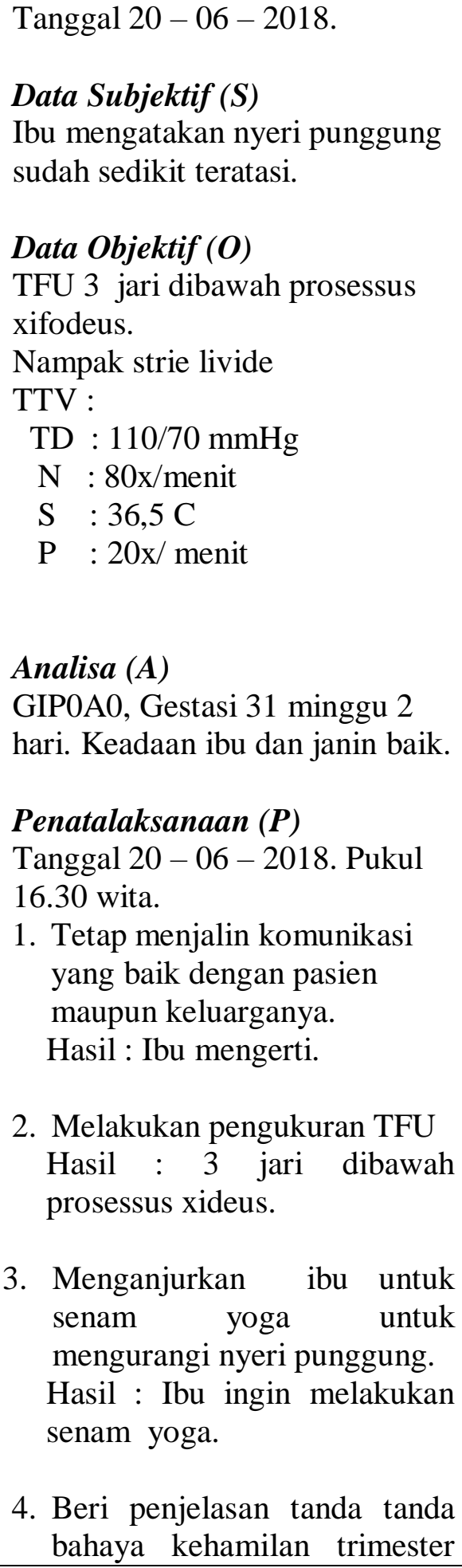 \\
\hline
\end{tabular}




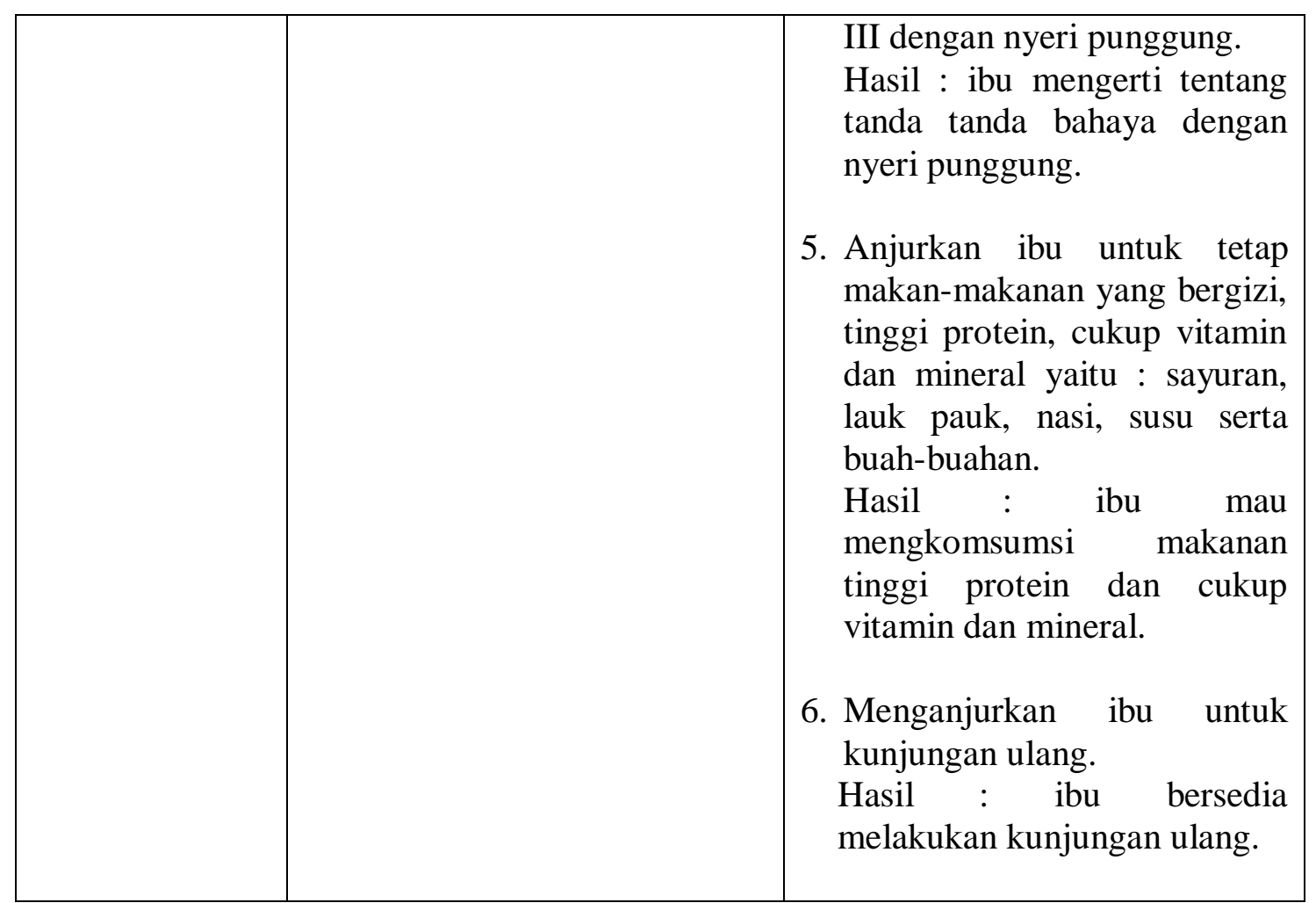

sekarang usia kemahilannya 34

\section{Pembahasan}

Kasus 1 dan 2

1) Pengkajian

$\mathrm{Ny}$ " $\mathrm{H}$ " berumur 35 tahun mengetahui ini kehamilan ketiganya sudah pernah melahirkan dan sekarang usia kehamilannya 37 minggu 4 hari. Adapun keluhan yang sering dirasakan adalah nyeri perut bagian bawah dan sering kencing-kencing dan berdasarkan pemeriksaan fisik yang dilakukan oleh $\mathrm{Ny}$ " $\mathrm{H}$ " tonus otot tampak kendor, TFU $31 \mathrm{~cm}$, pernah menggunakan alat kontrasepsi $\mathrm{KB}$ suntik 3 bulan yang telah digunakan sedangkan Ny "H" berumur 28 tahun mengetahui ini kehamilan yang pertama dan minggu 6 hari.adapun keluhan yang dirasakan adalah nyeri punggung,tonus otot tambak tegang,TFU $29 \mathrm{~cm}$.

2) Analisis Masalah

Pada saat melakukan pemeriksaan Leopold Ny "H" dan Ny"H" merasakan disisi kiri perutnya ditandai bahwa janin tunggal dengan hasil pemeriksaan palpasi Leopold yaitu teraba satu kepala, satu bokong, satu punggung, serta DJJ terdengar kuat pada sisi kanan perut ibu dan pembesaran perut sesuai dengan umur kehamilan.

3) Masalah Potensial

Tidak ada data yang mendukung untuk dilakukan pemeriksaan penunjang. 
4) Tindakan segera

Tidak ada data yang menunjang.

5) Perencanaan

Dalam

pembuatan

perencanaan

penulis

melakukan sesuai data yang

diperoleh dan disesuaikan

dengan kebutuhan dan keadaan

ibu. Penetapan yang

dimaksudkan untuk menjadi

pedoman dalam suatu tindakan.

Sedanngkan pada kasus $\mathrm{Ny}$

"H" dan Ny "H" melakukan

tindakan asuhan kebidanan

yaitu, observasi keadaan

umum, tanda-tanda

vital,menganjurkan untuk

mengkomsumsi makanan yang bergizi dan tinggi protein, menganjurkan ibu untuk senam hamil dan yoga, menjelaskamn tanda-tanda bahaya nyeri punggung dan perawatan payudara.

6) Implementasi

Berdasarkan data dari Ny "H" dan Ny"H" yang diperoleh yaitu ibu mengeluh sering buang air kecil dan nyeri punggung hal ini sesuai dengan teori yang menyatakan bahwa sering buang air kecil nyeri punggung yang dirasakan akibat adanya tekanan dari janin dan perubahan hormon.

7) Evaluasi

Hasil pemeriksaan pada $\mathrm{Ny}$ "H" menunjukkan hasil yang positif
Pukul 14.30 wita TD: $120 / 70$ $\mathrm{mmHg}$, asuhan pasca tindakan sudah diberikan dan sudah mengetahui keadaannya sekarang.

Sedangkan pada Ny"H" jam 15.30 wita TD: 110/70 $\mathrm{mmHg}$, dan asuhan pasca tindakan sudah dilakukan dan sudah mengetahui keadaannya sekarang.

Dengan melihat hasil yang diperoleh seperti yang telah diuraikan diatas dapat disimpulkan bahwa tujuan yang ingin dicapai pada kedua kasus tersebut sebagian besar dapat terevaluasi dengan yang diharapkan.

Dengan demikian pada tinjauan dan studi kasus pada kedua kasus dilahan praktek secara garis besar nampak adanya persamaan karena masalah dapat teratasi dengan baik.

8) Catatan Perkembangan

Pada pemantauan hari ke 6 pada kasus ini klien mengatakan masih merasakan buang air kecil dan nyeri punggung tetapi sering buang air kecil dan nyeri punggung yang dirasakan sudah mulai teratasi karena klien bersedia melakukan senam hamil dan yoga. 


\section{PENUTUP}

\section{Kesimpulan}

Berdasarkan studi kasus yang telah dilakukan pembahasan "Studi kasus kebidanan pada ibu hamil trimester III dengan nyeri punggung di Puskesmas Wonomulyo Polewali Mandar" yang di jabarkan dengan cara membandingkan dua pasien dengan kasus yang sama mulai dari pengumpulan data sampai dengan evaluasi maka penulis dapat mengambil kesimpulan.

Pengkajian

Penulis melakukan pengakajian Studi kasus ibu hamil trimester III dengan nyeri punggıno Anamnesa, pemeriksaan fi 80 pemeriksaan dalam serta pemeriksaan penunjang. Setelah dilakukan anamnesa diperoleh dua pasien bernama $\mathrm{Ny}$ " $\mathrm{H}$ " berumur 35 tahun, mengatakan ini kehamilan ke tiga dan sering buang air kecil dan nyeri punggung sekarang sudah teratasi secara perlahan-lahan. Dan pada pasien Ny "H" berumur 28 tahun, mengatakan ini kehamilan pertama dan mengalami keluhan nyeri punggung dan sekarng sudah teratasi secara perlahanlahan.

Analisis Masalah

Berdasarkan data perkembangan pada kasus ini, dapat ditegakkan diagnosis kebidanan $\mathrm{Ny}$. $\mathrm{H}$ usia 35 tahun GIIIPIIA0 usia kehamilan 37 minggu 4 hari, kehamilan dengan sering buang air kecil dan nyeri punggung dan Ny. H usia 28 tahun usia kehamilan 31 minggu 2 hari, kehamilan dengan nyeri punggung.Penulis mengatakan tidak ada data diagnosa masalah potensial yang berarti kehamilan ibu dalam keadaan normal $\mathrm{Ny}$. $\mathrm{H}$ dan Ny. H tidak didapatkan tandatanda masalah potensial.

Tindakan Segera

Rencana tindakan tidak dilakukan. Evaluasi

Evaluasi adalah tahapan penilaian terhadap keberhasilan asuhan yang telah diberikan pada dua pasien dengan kasus yang sama penulis mendapatkan hasil evaluasi pada $\mathrm{Ny}$. $\mathrm{H}$ dan $\mathrm{Ny}$. $\mathrm{H}$ dalam kedaan baik.

\section{Saran}

Berdasarkan kesimpulan bahwa konsep teori merupakan landasan penatalaksanaan praktek dilapangan sehingga penulis mengajukan saransaran sebagai berikut:

Bagi profesi

Dapat menjadi menjadi bahan masukan bagi bidan dalam meningkatkan kualitas pelayanan dan pelaksanaan asuhan kebidanan terutama pada ibu hamil trimester III khususnya nyeri punggung.

Bagi puskesmas wonomulyo 
Study kasus ini dapat dijadikan gambaran informasi serta bahan untuk meningkatkan manajemen kebidanan khususnya Asuhan Kebidanan pada ibu hamil trimester III dengan nyeri punggung yang diterapkan oleh lahan praktek.

Bagi Stikes Bina Generasi

Dapat menjadi menjadi bahan masukan bagi pendidikan untuk

DAFTAR PUSTAKA

Dr. Merryani, SKM., M.Kes, 2016. Peranan Gizi dalam Siklus Kehidupan: Editor, Suwito. Jakarta.

dr. Judi Junaidi Edjun, SpOG, 2017. Panduan Cerdas Pemeriksaan Kehamilan: Edisi 4. Penerbit Pustaka Bunda.

dr. Ida Ayu Chandranita Manuaba, SpOG, 2009. Buku Ajaran Patologi Obstetri

Edisi 4. Jakarta: Penerbit Buku Kedokteran EGC

$\mathrm{dr}$

Surinah, 2010

AsuhanKebidananUntukKehamilan, Jakarta

Elda Yosefni SST, M.Keb \& Sonya Yulia, S.Pd., M.Kes, 2017. Kebidanan Teori dan Asuhan: Edisi 3. Jakarta: Penerbit Buku Kedokteran EGC

GustiayuMandriwati,2016AsuhanKebidanan padamasa antenatal. Yogyakarta :pustakabelajar.

Ida Ayu Chandranita Manuaba, 2010. Ilmu Kebidanan, Penyakit kandungan dan menambah informasi, pengetahuan, menambah referensi dan perpustakaan yang dapat dijadikan acuan bagi mahasiswa kebidanan dalam melaksanakan asuhan kebidanan khususnya pada ibu hamil trimester III dengan nyeri punggung.

KB: Editor, Monica Ester, Estu Tiar. Jakarta: EGC

Kusmaryadi, (2011), Nyeri punggung selama kehamilan.

Krisnadi. 2010, sinopsis Yoga Untuk Kehamilan Sehat, Bahagia dan penuh makna.

Kusumayanti,

yuni,dkk,2009perawatanibuhamil, Yogyakarta

Musdalifah,S.Pd.S.SiT.MSc.2009. Panduan Asuhan Kebidanan Ibu Hamil: Editor, Ari Setiawan, M.Pd. Jakarta: EGC

Miratu Megasari, SST., M.Kes, 2015. Panduan Belajar Asuhan Kebidanan: Editor, Ani Triani, SST., M.Kes. Yogjakarta: EGC

Muheri, 2010 panduanbelajarAsuhanKebidanan: yogyakarta

Prawirohardjo.2009. Buku Acuan Nasional Pelayanan Kesehatan Maternal dan Neonatal . Yayasan Bina Pustaka Sarwono ,Jakarta 
Prawirohardjo.2010. Ilmu Kebidanan .Yayasan Bina Pustaka Sarwono,Jakarta.

Ruiyah A, Yuliani L,2010.

Konsepkebidanan, Jakarta

Sarwono

prawiroharjo,2009.

Ilmukebinanan.Yayasanbinapustaka,

Jakarta.
Sulistyawati,

Ari,2009.Asuhankehamilanpadamasakehami lan, Jakarta: salembamedika.

Tim Navari, 2011. Buku Pintar Ibu Hamil. Edisi 2. Penerbit PT Elex Media Komputindo Kelompok Gramedia Jakarta.

Winjosastrotro 2009, obstetric fisiologi, yayasanbinapustaka, Jakarta. 